
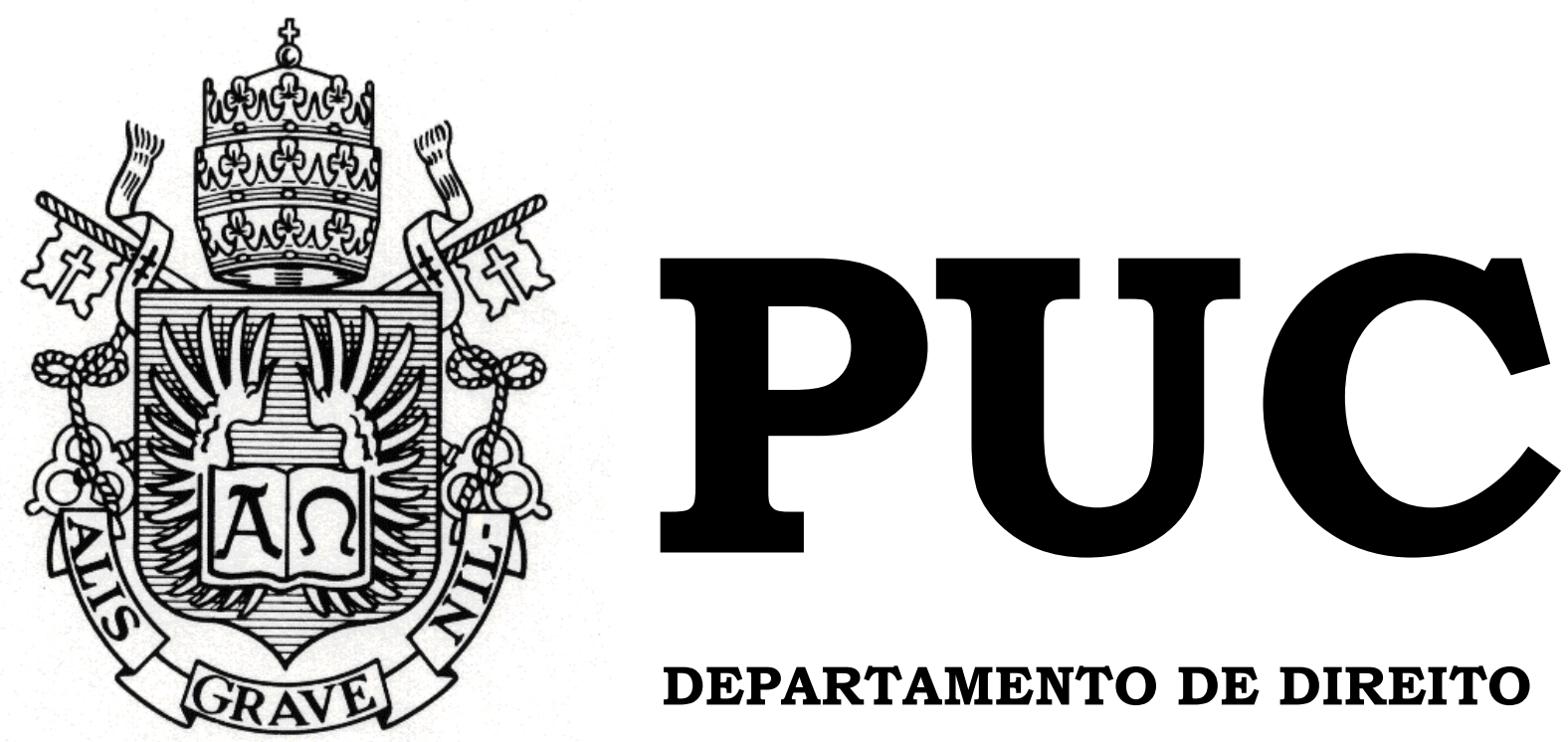

DEPARTAMENTO DE DIREITO

\title{
PRECEDENTE COMO FONTE INSTITUCIONAL: ENTRE O TEXTO E A NORMA
}

por

PAULA LEMOS PENTEADO

ORIENTADORA: RACHEL NIGRO

2016.2

PONTIFÍCIA UNIVERSIDADE CATÓLICA DO RIO DE JANEIRO

RUA MARQUÊS DE SÃO VICENTE, 225 - CEP 22453-900

RIO DE JANEIRO - BRASIL 


\title{
PRECEDENTE COMO FONTE INSTITUCIONAL: ENTRE O TEXTO E A NORMA
}

\author{
por \\ PAULA LEMOS PENTEADO
}

Monografia apresentada ao Departamento de Direito da Pontificia Universidade Católica do Rio de Janeiro (PUC-Rio) para a obtenção do Título de Bacharel em Direito.

Orientadora: Rachel Nigro

2016.2 
Dedico ao meu pai Wagner, minha mãe Míriam e minha irmã Carolina.

In memoniam ao meu pai Paulo Sérgio Guimarães Penteado. 


\section{AGRADECIMENTOS}

Agradeço, em especial, a minha família por me dar, todos os dias, o maior amor do mundo. Ao meu pai Wagner e minha mãe Míriam, por terem feito de tudo para que a conclusão desse curso (e de muitas outras realizações) fosse possível. À minha irmã, por vir ao mundo para completar o amor dessa família e estar ao meu lado incondicionalmente. Aos meus primos Felipe, Rafael e Lucas Lemos e a minha vó Luiza, xodós do meu coração.

A minha falecida vó Taís, minha vó Bernadete e meu Vô Wagner.

A minha Tia Clarice que tanto amo.

Agradeço a minha orientadora Rachel Nigro e seu pupilo, Caio Freitas pela enorme generosidade. Sem eles esse trabalho não seria possível.

Agradeço ao meu namorado, Igor Nacife, pelo amor, pelo companheirismo, e pelo carinho que tem comigo todos os dias. Ainda, pela especial dedicação e paciência nessa reta final, me estendendo à mão e permanecendo ao meu lado (literalmente) quando mais precisei, além de tornar momentos de estresse em felicidade.

Agradeço a melhor amiga que poderia ter, Letícia Vidaurre, por ser minha eterna protetora e protegida nessa longa caminhada da vida.

Ao casal mais fofo de amigos, Luiza Martins e Roberto Saad, por fazerem dos meus finais de semana os mais especiais.

As minhas amigas mais que queridas Jessica Lopez e Barbara Areias, por serem exatamente como são e terem entrado na minha vida pra nunca mais sair. 
Aos meus companheiros de trabalho, Ângela Costa, Diogo Mendes, Dr. Marco Antônio Azevedo Junior e Maria Cláudia por serem tão queridos e especiais no meu dia-a-dia e durante a elaboração deste trabalho.

Agradeço, ainda, aos melhores amigos que essa faculdade pôde me dar: Deborah Torres, Ian Schneider, Aglaia Chalréo, Maria Eduarda Gamborgi, Renato Gomide, Jéssica Hallana e Juliana Tonini. Aqueles que, além de fazerem dessa jornada a melhor impossível possível, contribuíram, diretamente, a cada prova, trabalho e período para a minha formação pessoal e profissional. 


\section{RESUMO}

Este presente trabalho monográfico tem por objetivo estudar o sistema de precedentes adaptado do Commom Law ao Civil Law como construtor do direito, analisar e problematizar seu processo de formação, ressaltando-se, especificamente, a problemática linguístico-filosófica presente na produção da norma emanada do precedente e as consequências da sua aplicação. Também é objeto deste trabalho apresentar brevemente como o Novo Código de Processo Civil aborda o precedente como fonte institucional e quais consequências a adoção desse instituto traz para o ordenamento jurídico brasileiro.

Palvaras-Chave: precedentes vinculantes - fonte institucional - extração da ratio decidendi - indeterminação da linguagem - textura aberta - entre texto e norma - Novo Código de Processual Civil. 


\section{SUMÁRIO}

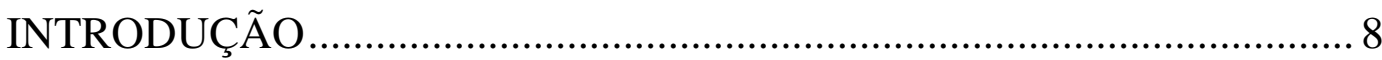

1. A função dos precedentes judiciais....................................................... 10

1.1 A função desempenhada pelos precedentes no Commom Law e no

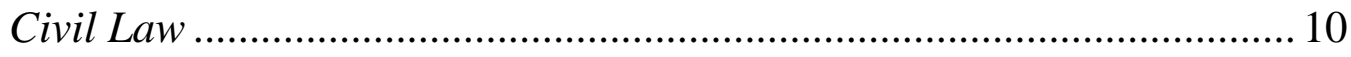

1.2 A função desempenhada pelos precedentes no Brasil ..................... 13

2. Determinação da norma emergente do precedente .................................. 16

2.1 Precedente, Jurisprudência e Súmula................................................ 16

2.2 Jurisprudência como integração de lacuna e a importância da argumentação jurídica para a formação do precedente .............................. 18

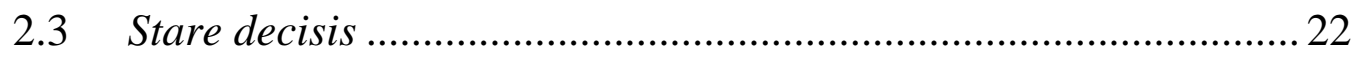

2.4 Ratio decidendi (ou holding) e obiter dictum ................................. 23

3. A indeterminação da linguagem ............................................................. 29

3.1 Filosofia pragmática da linguagem ................................................ 29

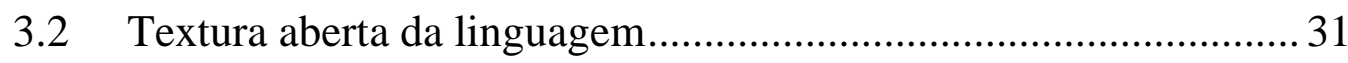

3.3 Diferença entre texto e norma........................................................ 37

4. O instituto dos precedentes no Novo Código de Processo Civil ........... 41

4.1 Os dispositivos legais pertinentes .................................................. 42

4.2 Consequências da adoção do sistema de precedentes no direito

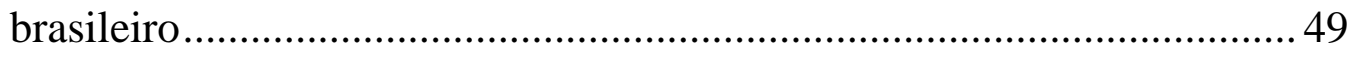

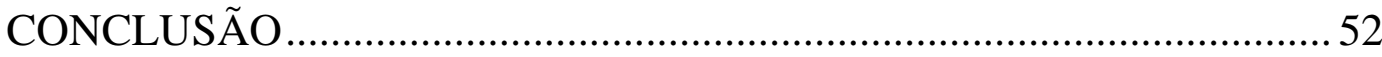

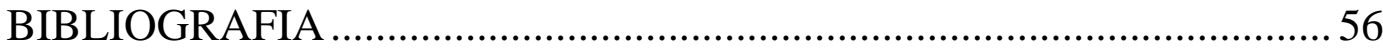




\section{INTRODUÇÃO}

Uma das maiores inovações do Novo Código de Processo Civil foi importar o sistema de precedentes para nosso ordenamento jurídico, trazendo à tona discussões acerca da sua aplicabilidade e funcionalidade diante da nossa realidade jurídica.

Tendo em vista ser um tema novo e ainda não amadurecido, pouco se sabe efetivamente sobre ele, e até mesmo a doutrina encontra dificuldades para propor uma teoria dos precedentes pronta e acabada. Se nem a doutrina se sente preparada ainda para firmar entendimentos sobre o assunto, não é preciso nem dizer que este trabalho também não tem essa pretensão.

O que se almeja aqui é estimular a reflexão sobre a aplicação do sistema de precedentes, dando ênfase à problemática linguístico-filosófica, tema este que tanto me encantou ao longo da faculdade. Dentro dos limites de um trabalho monográfico, tentei demonstrar o quanto a filosofia da linguagem é de suma importância para a construção do Direito na sociedade, e em especial, para a construção e aplicação dos precedentes como novo instituto do Direito Processual Civil.

Para cumprir tal objetivo, dividi o trabalho em quatro partes. Primeiro, para iniciar o estudo sobre o instituto do precedente, busquei expor as funções que ele possui originalmente no Commom Law, evidenciando as semelhanças e distinções em relação ao Civil Law, e, logo após, apontando as funções que os precedentes exercem no Brasil.

$\mathrm{Na}$ segunda parte apresento a determinação da norma emergente do precedente, distinguindo brevemente, de início, este da jurisprudência e das súmulas. Feita essa distinção, faço um paralelo entre a jurisprudência como integração de lacuna e a importância da argumentação jurídica para a formação do precedente, a fim de demonstrar a complexidade de se 
determinar a ratio decidendi .Para tornar essa demonstração possível, apresento e estabeleço definições para conceitos imprescindíveis do sistema de precedentes, quais sejam: stare decisis, ratio decidendi e obiter dictum.

Estabelecidas essas definições, parto para a terceira etapa, a qual vê na indeterminação da linguagem algo que dificulta a extração da norma geral aplicável aos casos semelhantes posteriores e que, ao mesmo tempo, também pode ser encarado como uma oportunidade para se buscar a justiça e o equilíbrio na tomada de decisão, já que o fruto de sua interpretação tende a diminuir os excessos da aplicação da lei.

Sobre a indeterminação da linguagem abordo o tema da textura aberta dos termos jurídicos e a importante distinção entre texto e norma, pois são pontos que muito contribuem para a reflexão sobre a formação e aplicação do precedente.

A quarta e última etapa busca apresentar como esse novo instituto foi abordado pelo Novo Código de Processo Civil, expondo de forma concisa algumas mudanças que ele poderá acarretar para a prática jurídica brasileira. 


\section{A função dos precedentes judiciais}

\subsection{A função desempenhada pelos precedentes no Commom Law e no Civil Law}

Acerca do tema desta monografia, é importante ressaltar, de início, a função desempenhada pelos precedentes judiciais de modo geral. Para isso, no entanto, é preciso passar pela diferença da função dos precedentes nos dois principais tipos de sistema jurídicos, quais sejam: a Commom Law e a Civil Law.

A principal diferença entre os referidos sistemas, como é de conhecimento geral, é que o precedente é utilizado como fonte principal do seu direito. Enquanto o Commom Law tem as decisões judiciais como "principal irradiador de normas", o Civil Law tem a lei como protagonista da manifestação do seu direito (Mello, 2008, p.12).

No sistema do Commom Law, a formulação das normas é feita, prioritariamente, caso a caso. Ou seja, a partir de um caso concreto, formula-se uma premissa que será utilizada em situações análogas.

No sistema do Civil Law a solução do caso concreto emana, primordialmente, da aplicação da lei. As decisões judiciais nesse sistema, a priori, possuem papel secundário, na medida em que auxiliam na atividade interpretativa da aplicação da norma ao fato, ou são aplicadas em caso de lacuna da lei.

Apesar das diferenças pontuais citadas, ambos os sistemas estão em constante transformação e, obviamente, evoluem de forma a aproximar-se, conforme narra Patrícia Perrone de Mello:

"É de se notar, contudo, que tais sistemas não se desenvolveram de forma estanque e que tampouco permanecem estagnados e incomunicáveis. Ao longo de sua formação sofreram influências recíprocas e, hoje, se encontram em claro processo de aproximação." (Mello, 2008, p.13). 
Segundo Patrícia Perrone, a aproximação do direito inglês com a legislação codificada se deu, resumidamente, por quatro fatores históricos: "afirmação da supremacia do Parlamento, o triunfo dos ideais democráticos, a concepção do Estado de bem-estar social (Welfare state) e o ingresso do país na Comunidade Europeia”. (Mello, 2008, p. 27). Já o direito norteamericano tem contornos próprios e buscou inspiração no direito romano e no direito inglês para garantir a repartição do poder vertical e horizontal, ocasionando na adoção de uma "constituição escrita, abstrata, geral e rígida, portanto, uma lei no estilo romano que dominaria o seu sistema jurídico" (Mello, 2008, p. 37) ${ }^{1}$.

O direito romano, base do Civil Law, curiosamente, se aproxima do Commom Law desde o princípio. Isso porque, de início, "se destacava por ter um caráter prático, casuístico e problemático, em que as soluções vinham do caso concreto, inspirando decisões futuras, de forma semelhante à Commom Law, em que o direito subjetivo vai sendo criado mediante expedientes concretos de caráter processual". (Cappelletti, 2005, p. 417418).

Muito embora o direito romano fosse, anteriormente, casuístico e problemático, sua principal fonte, hoje, é a lei. "O Civil Law concebe a regra de direito como um comando normativo geral, abstrato, enunciado, em parte, com base em considerações sobre justiça, moral e política, e, em parte, como fruto de uma reflexão sistemática empreendida a parte da prática." (Mello, 2008, p. 46).

Com o objetivo de tornar o direito mais fragmentado e sistemático, sua generalidade e abstração fazem com que a decisão final dependa da interpretação das normas existente por um juiz. A doutrina, os princípios

\footnotetext{
${ }^{1}$ Claramente, há muitos outros pontos de convergência entre um sistema e outro, além dos citados acima. Entretanto, não é o objetivo desse presente trabalho esgotar tais pontos. O que aqui interessa é introduzir de forma sucinta a influência da utilização dos precedentes no nosso ordenamento. Sobre o tema, Patrícia Perrone faz um tópico didático sobre os pontos de identidade e intercâmbio (Mello, 2008, p. 52-54).
} 
gerais, os costumes e a jurisprudência ${ }^{2}$ são fontes do direito que, além de contribuírem para a interpretação das normas, contribuem para o desenvolvimento e construção do direito, influenciando, inclusive a ação do legislador ao preencher conceitos jurídicos e solucionar conflito entre normas.

Hoje, vemos a atuação cada vez maior e mais relevante da jurisprudência no Civil Law. Isso se dá, segundo Patrícia Perrone, à retomada e desenvolvimento da hermenêutica concretizadora de Konrad Hesse3 e às teorias argumentativas de Theodor Viehweg que visam formular respostas para situações não previstas nos diplomas legais, os quais se tornaram obsoletos mediante a evolução social e econômica:

"Paulatinamente, verificou-se a retomada e o desenvolvimento de teorias hermenêuticas que colocaram em relevo o papel das decisões judiciais: defenderam uma análise dos litígios focada no problema, buscando sua composição a partir dos diversos argumentos e pontos de vista (tópicos) suscitados pelas partes e de seu teor persuasivo; observaram que o direito só se define à luz do caso concreto, por um processo circular que parte da précompreensão do texto, passa pelas peculiaridades da demanda, e retorna à norma, precisando seu conteúdo; pregaram que as pessoas não são governadas apenas por regras explícitas, mas também por princípios que decorrem dessas regras; e, demonstraram, finalmente, que a atividade jurisdicional pressupõe que os magistrados formulem juízos de valor, a partir dos fatos e dos argumentos apresentados pelas partes, legitimando-se a sua função criativa." (grifo meu) (Mello, 2008, p. 49-50).

A questão é que o direito da Civil Law acaba ficando mais adstrito a códigos, que por mais que sejam atualizados de tempos em tempos, não conseguem acompanhar as mudanças e evoluções sociais, nem abarcar a todos os fatos relevantes. Com isso, surge a necessidade de se explorar as decisões judiciais (e outras fontes do direito também) a fim de equilibrar tal descompasso. Além disso, a autora aponta a aproximação entre o direito e

\footnotetext{
${ }^{2}$ Sobre o uso dos conceitos de "jurisprudência" e "precedente", há que se fazer uma ressalva, tendo em vista que são institutos diferentes, porém muito próximos. Neste ponto do trabalho ainda usaremos os termos sob um significado em comum, qual seja, o de "decisões jurídicas como fonte do direito".

${ }^{3}$ Interessante notar que Konrad Hesse foi o primeiro jurista conhecido e renomado a reproduzir as posições da teoria estruturante do direito Friedrich Müller a partir de manuscritos da época em que este era seu assistente em 1964. (Müller, 2013, p. 231)
} 
moral e a exaltação de considerações éticas, decorrente da centralidade do direito constitucional pós-positivista, também como marcos que situam essa flexibilização para um sistema mais aberto (Mello, 2008, p.51-52).

\subsection{A função desempenhada pelos precedentes no Brasil}

Podemos perceber que o ordenamento brasileiro recebeu influências tanto do Commom Law, quanto do Civil Law. Primeiramente, herdou da colonização portuguesa o sistema romano, o qual tem como principal fonte do direito a lei. Além disso, foram introduzidos os assentos e enunciados judiciais que possuíam caráter normativo e dirimiam dúvidas acerca da interpretação das normas e lhe conferiam uniformidade. Isso, mais tarde, constituiria os prejulgados e as súmulas utilizados até hoje.

As influências do Commom Law se firmaram no controle de constitucionalidade, na medida em que se baseou profundamente no constitucionalismo dos Estados Unidos. No Brasil, Patrícia Perrone destaca algumas medidas históricas nesse sentido: a adoção de um sistema difuso de judicial review na Constituição de 1891, a possibilidade do Senado Federal suspender leis e atos declarados inconstitucionais pela Constituição de 1934 e a fiscalização abstrata feita por meio de representação de inconstitucionalidade de atos normativos federais e inconstitucionais introduzido pela Emenda Constitucional no 16/19654 (Mello, 2008, p. 55$56)$.

Mas só com a redemocratização do país e sob a vigência da Constituição Federal de 1988 a jurisprudência passou a desempenhar um considerável papel no nosso ordenamento jurídico. A restauração do Estado Democrático de Direito no Brasil fez emergir uma nova hermenêutica

\footnotetext{
${ }^{4}$ Essa última (a fiscalização abstrata feita por meio de representação de inconstitucionalidade de atos normativos federais e inconstitucionais introduzido pela Emenda Constitucional $\mathrm{n}^{\circ}$ 16/1965), especificamente, é uma influência europeia nas ideias de Kelsen e na Constituição Austríaca de 1920) (Mello, 2008, p. 55-56)
} 
constitucional, a qual colocou a nova Carta como centro do ordenamento jurídico, ampliando a pretensão normativa do seu texto, inovando nos instrumentos de revisão judicial, baseando-se em um grande rol de direitos fundamentais, ponderações de princípios, argumentações valorativas e outros, conferindo à jurisprudência uma função essencial em tais tarefas (Barroso, 2005, p. 57).

Nesse cenário, deu-se a ampliação da atuação dos precedentes constitucionais com efeitos vinculantes e gerais, como afirma Patrícia Perrone:

Verificou-se ademais, com a promulgação da nova Carta, a ampliação dos precedentes constitucionais com efeitos vinculantes e gerais, que em virtude da extensão dos legitimados para promover o controle concentrado, antes restritos ao Procurador Geral da República, quer por conta da efetiva introdução no ordenamento brasileiro de novos instrumentos com tal eficácia, inclusive através de emendas constitucionais e da legislação infraconstitucional. Paralelamente, algumas leis ordinárias conferiram, ainda, efeitos impositivos mais brandos, para além do caso concreto, à jurisprudência dominante do STF e dos tribunais, e às súmulas. (Mello, 2008, p. 58).

Atualmente, o sistema de aplicação dos precedentes está em maior evidência tendo em vista o Novo Código de Processo Civil promulgado em 2015. Não por acaso o novo Código foi sensível à questão dos precedentes, objetivando solucionar alguns problemas do sistema judiciário brasileiro.

O professor Ronaldo Cramer em sua tese de doutorado, atenta, especificamente, para seis funções do precedente em nosso ordenamento processual. São eles: “(a) ser modalidade de argumentação jurídica; (b) uniformizar a compreensão da norma jurídica; (c) uniformizar a jurisprudência; (d) gerar previsibilidade da resposta judicial; (e) criar agendas; e (f) colaborar para a formatação da identidade nacional." (Cramer, 2016, p.100).

A preocupação com a segurança jurídica, com o elevado número de processos cumulado com a necessidade de dar aos julgados maior uniformidade, qualidade, credibilidade, bem como diminuir a 
discricionariedade das decisões ensejam o aumento da utilização desse sistema com efeitos vinculativos a fim de aprimorar a administração da justiça atual. 


\section{Determinação da norma emergente do precedente}

\subsection{Precedente, Jurisprudência e Súmula}

Ao longo desse trabalho, pretende-se, haja vista a importância da atuação dos precedentes como construtor do direito tal como apontado acima, analisar e problematizar seu processo de formação, ressaltando-se, especificamente, a problemática linguístico-filosófica presente na produção da norma emanada do precedente e as consequências da sua aplicação.

Para Ronaldo Cramer, a principal distinção entre jurisprudência e precedente é quantitativa, ou seja, o precedente refere-se à decisão de apenas um caso e a jurisprudência à repetição das decisões no mesmo sentido, sobre a mesma questão. E explica que, "na verdade, [...] em primeiro lugar, tem-se o julgado, que pode ser um precedente ou não, a depender se este criou uma tese jurídica. $\mathrm{O}$ precedente, quando reiteradamente aplicado, vira jurisprudência, e esta, se for firme quanto à posição do tribunal, transforma-se em súmula." (Cramer, 2016, p. 72-73).

Para Fredie Didier et al, "em sentido lato senso, o precedente é a decisão judicial tomada à luz de um caso concreto, cujo elemento normativo pode servir como diretriz para o julgamento posterior de casos análogos" (Didier Jr. et al, 2016, p. 455).

Já Patrícia Perrone não chega, em sua obra, a conceituar de forma específica o que entende por precedente. Entretanto, a passagem a seguir indica seu entendimento:

As situações da vida cotidiana [...] demonstram que os casos se compõem de alguns elementos que os individualizam, consistentes nos fatos considerados relevantes, nos fundamentos e na questão valorativa posta pelos mesmos e decidida. A partir destes elementos é possível formular uma regra, que, diante de novas situações, se aperfeiçoará e se redefinirá, tendo em conta as decisões já produzidas. Buscar-se-á, então, enunciar um princípio mais genérico, que sirva de base a todas elas e que oriente soluções futuras e inéditas. (Mello, 2008, p. 116). 
Atualmente, a meu ver, o conceito mais completo de precedente é o formulado por Ronaldo Cramer, qual seja:

$\mathrm{O}$ conceito de precedente tem dois sentidos. Em sentido próprio precedente é a decisão judicial que fixou a tese jurídica (norma jurídica) que deverá ser seguida pelas demais decisões em casos idênticos. Chama-se esse sentido de próprio porque é o mais usado, é intuitivo e aparece em todos os sistemas processuais, independentemente de pertencerem ao Civil Law ou ao Commom Law. Em sentido impróprio, precedente constitui a própria norma jurídica criada pela decisão judicial, ou seja, a tese jurídica que servirá de parâmetro decisório para casos idênticos. [...] Denomina-se esse sentido impróprio, porque simplesmente é menos utilizado. [...] Normalmente, o precedente é visto de maneira retrospectiva. No Commom Law, por exemplo, o julgado ao tempo em que é proferido, ainda não constitui um precedente, somente se tornará um se assim for discernido pelas futuras decisões. São somente as decisões posteriores que, ao olharem para o passado, identificarão na jurisprudência se existe um precedente para solucionar o caso sob julgamento. (Cramer, 2016, p. 77-78).

Seguindo, em parte, o entendimento exposto acima, precedente é o primeiro julgado que cria uma norma jurídica geral a ser adotada em casos posteriores que possuam semelhanças de fato e identidade de tese jurídica. Isso porque o precedente surge a partir da interpretação do texto de regras, lato sensu, à luz das circunstâncias e das teses específicas da causa, levando à identificação de uma norma (em que, como veremos adiante, a ratio decidendi constitui seu elemento nuclear), enquanto a jurisprudência é a sua reiteração.

Faz-se mister uma última e breve distinção entre precedente e súmula, na medida em que não se confundem. Súmula é "substantivo coletivo e significa conjunto dos enunciados representativos da jurisprudência de um tribunal" (Cramer, 2016, p.81). Logo, é uma síntese da tese jurídica criada pelo precedente que retrata um entendimento consolidado.

Em síntese, se pensarmos nesses institutos como uma linha do tempo, teremos:

$1^{\circ}$ julgado que criou nova norma (ratio) $\rightarrow$ Precedente $\rightarrow$ Jurisprudência $\rightarrow$ Súmula 
O primeiro julgado que criou a norma pode virar uma norma individual ou uma norma geral. Se essa norma geral for utilizada para solucionar casos semelhantes futuros, tornar-se-á um precedente. Esse, quando utilizado quantitativa e reiteradamente torna-se jurisprudência, que, por sua vez, quando passa a ter um conjunto de enunciados representativos, transforma-se em súmula.

\subsection{Jurisprudência como integração de lacuna e a importância da argumentação jurídica para a formação do precedente}

A atuação dos precedentes nos países de língua inglesa é, com certeza, muito mais comum do que para nós que vivemos imersos em ordenamentos jurídicos de tradição romano-germânica. No Brasil, até a promulgação do Novo Código de Processo Civil, a utilização da jurisprudência e dos precedentes era tida como uma fonte opcional da argumentação jurídica.

Isso se dá porque a maioria dos profissionais da área considera como fonte formal aquela estabelecida em lei. $\mathrm{O}$ art. $4^{\circ}$ da Lei de Introdução às Normas do Direito Brasileiro estabelece que, no caso de omissão da lei, o caso concreto será decido de acordo com analogia, costumes e princípios gerais de direito, sem incluir, portanto, a jurisprudência.

Embora seja difícil negar que a jurisprudência influencia de maneira significante a formação do próprio direito brasileiro e a argumentação jurídica, ainda se hesita em considerá-la como fonte formal. Muito diferente do que acontece nos países da Commom Law, o qual adota o princípio do stare decisis, que sequer surgiu de lei, pelo contrário, foi introduzida de forma gradual pelos próprios juízes, como será explicado mais adiante.

Conforme explicitado acima, na omissão da lei, o juiz decidirá com base em outras fontes. Chamamos tal omissão de lacuna e essa possui duas formas de acontecer: i) quando o texto legal não dispõe ou não é claro na 
regulamentação de certa norma/conduta (lacuna neutra); ou ii) quando é usada de forma avaliativa, ou seja, quando o texto legal não prevê certas situações que deveriam ter sido consideradas, e são omissas. (Struchiner et al, 2016, p. 103-104).

Noel Struchiner et al, em sua obra sobre teoria da argumentação jurídica, apontam que há quatro tipos de argumentação, divididas em duas subcategorias. A argumentação prática e a teórica, bem como a institucional e a substantiva. Sobre os argumentos teóricos e práticos, estabelece como base a importante distinção entre fato ("ser") e norma ("dever ser"), já que as conclusões dos argumentos teóricos estão no plano do "ser" e as conclusões dos argumentos práticos estão no plano do "dever ser".

Mas, se pudéssemos encaixar todos os termos da língua portuguesa nessas duas categorias, esse tema monográfico seria inútil. Fato é que existem termos que não são nem factuais nem prescritivos. Nesse sentido, Noel Struchiner et al propõem que, na verdade, existem três categorias: "1) termos puramente factuais (por exemplo, racismo é antigo); 2) termos puramente avaliativos/prescritivos (o racismo é ruim); 3) termos mistos ou densos (o racismo é antiquado)" (Struchiner et al, 2016, p. 33-34) e que apenas a de números 2 e 3 são argumentos práticos5.

Os argumentos práticos são divididos entre os outros dois tipos mencionados acima: práticos substantivos e práticos institucionais. Como já vimos, ambas atuam no plano do "dever ser", mas se distinguem nas suas razões. Os argumentos substantivos são de cunho moral, político, econômico, social e outros são de razões intelectuais livres que objetivam a busca do justo e do mais democrático. Já os argumentos institucionais são

\footnotetext{
${ }^{5}$ Para o presente trabalho, interessa estudar e avaliar o tipo de argumento que causa discussão acerca do seu significado/sentido.
} 
os que respeitam as regras e os procedimentos pré-estabelecidos no ordenamento $^{6}$ (Struchiner, 2016, p. 37-45).

Independente de ser a interpretação institucional ou substantiva, é importante refletirmos agora sobre o próprio ato de interpretar. Segundo Carlos Maximiliano, "é tarefa primordial do executor a pesquisa da relação entre o texto abstrato e o caso concreto" (...) Em resumo, é o que se chama interpretar, isto é, determinar o sentido e o alcance das expressões do Direito" (Maximiliano, 1991, p. 1).

Não obstante haver, no âmbito jurídico, divergência sobre o ato de interpretar, podemos dizer que, lato sensu, é o processo pelo qual se atribui sentido aos enunciados de textos normativos, visando à resolução de um caso concreto (Dimoulis, 2007, p. 172). Para Noel Struchiner et al, é "todo ato (intelectualmente exigente ou não) de discernir o sentido de um texto legal (obscuro ou não)" (Struchiner et al, 2016, p. 70-71), com destaque para o termo discernir, pois este, a seu ver, sugere que há um sentido préexistente do texto legal, mais claramente para os textos claros e menos para os textos obscuros.

Diante desses dois conceitos é imperioso ressaltar o uso de dois verbos que os distinguem: atribui-se sentido ou se discerne sentido. Assim surge a dúvida: com a interpretação, descobrimos sentidos preexistentes ou atribuímos sentido que o texto não carrega em si?

Noel Struchiner et al destacam que para Humberto Ávila a interpretação é um ato de decisão do intérprete que, ao decidir, constitui a significação e os sentidos do texto, e não uma mera descrição de um significado prévio. Isso porque, uma vez que o intérprete tem a livre escolha de qual método interpretativo adotará, estará escolhendo, também, o sentido do texto (Noel Struchiner et al, 2016, p. 89-90).

\footnotetext{
6 Vale ressaltar que Noel se posiciona ao dizer que a tese central de seu livro é a "tese institucional", que consiste na afirmação de que o mundo jurídico argumenta de forma predominantemente institucional (Struchiner, 2016, p. 37 a 45).
} 
Mister destacar a noção de interpretação feita por Ávila em sua obra sobre "Teoria dos Princípios":

[...] a interpretação não se caracteriza como um ato de descrição de um significado previamente dado, mas como um ato de decisão que constitui a significação e os sentidos de um texto. A questão nuclear disso tudo está no fato de que o intérprete não atribui "o" significado correto aos termos legais. Ele tão só constrói exemplos de uso da linguagem ou versões de significados - sentidos , já que a linguagem nunca é algo pré-dado, mas algo que se concretiza com o uso, ou, melhor, como uso.

Essas considerações levam ao entendimento de que a atividade do intérprete quer julgador, quer cientista - não consiste em meramente descrever o significado previamente existente dos dispositivos. Sua atividade consiste em constituir esses significados. Em razão disso, também não é plausível aceitar a ideia de que a aplicação do Direito envolve uma atividade de subsunção entre conceitos prontos antes mesmo do processo de aplicação. [...] é importante dizer que as condições de uso da linguagem funcionam como condições dadas da comunicação. "Expressions acquire their meaning when language is used" afirma Arnio. Bydinsky sustenta semelhante argumento: praticamente, a comunicação linguística humana é de tal modo construída, que, dentro de determinados limites, com determinadas palavras membros de uma dada comunidade linguística são vinculadas as mesmas ideias.

Por conseguinte, pode-se afirmar que o intérprete não só constrói, mas reconstrói sentido, tendo em vista a existência de significados incorporados ao uso linguístico e construídos na comunidade do discurso [...]. Exatamente por isso a atividade de interpretação traduz melhor uma atividade de reconstrução [...]. (grifo meu) (Ávila, 2010, p.32-33).

Por um lado, há de se concordar que interpretar é decidir por um sentido, o qual está relacionado com o uso desse termo, intrinsecamente ligado ao contexto em que está inserido. Entretanto, ressalvas precisam ser feitas com o intuito de relativizar o entendimento de Ávila, pois se assim fosse, estar-se-ia admitindo que o texto nunca traz um núcleo mínimo de sentido e que o intérprete sempre terá espaço para optar entre os sentidos, sem ter sua discricionariedade limitada, o que dificultaria e muito a formação de uma ratio das decisões judiciais.

Além disso, mesmo que o intérprete escolha qual método de interpretação deve utilizar, pode ocorrer de muitos deles apontarem para o mesmo sentido, e aí sim, um determinado sentido estaria engessado. Para a discussão acerca da formação da ratio, como veremos adiante, ainda que se 
tenha um engessamento com uma conclusão possível, os variados meios de se chegar a essa conclusão, acaba por enfraquecer o sentido da ratio.

\subsection{Stare decisis}

A expressão stare decisis tem origem do Latin: "stare decisis et non quieta movere", que significa "deixar quieto o que já foi decidido e não alterá-lo" (Perrone, 2008, p. 116) e foi incorporado definitivamente no caso London Tramways Company v. London County Council, pela House of Lords, em 1898.

Ficou determinado no referido julgado que as decisões das cortes superiores passariam a vincular as cortes inferiores, assim como as cortes passariam a ser vinculadas às suas próprias decisões. Surge, dessa forma, a política do Commom Law que obriga vertical e horizontalmente as cortes a seguirem seus próprios julgados.

Frederick Schauer divide os precedentes em verticais e horizontais. Isso justifica a vinculação vertical e horizontal do stare decisis. Os precedentes verticais são aqueles que, proferidos por um órgão, vincularão os órgãos inferiores, ou seja, há uma relação hierárquica institucional a ser respeitada (e por isso, seriam absolutamente vinculantes). Os precedentes horizontais são aqueles que, proferidos por um órgão, vinculará o próprio órgão que o proferiu (relativamente vinculantes). Isso é a doutrina do stare decisis (Barbosa, 2015, p. 32-33).

Veremos melhor adiante que, no caso brasileiro, esta distinção tornou-se importante haja vista o advento do art. 926 do CPC que introduziu a adoção do stare decisis no nosso ordenamento jurídico ao estabelecer que os tribunais devem uniformizar jurisprudência e mantê-la estável, íntegra e coerente: 
Art. 926. Os tribunais devem uniformizar sua jurisprudência e mantê-la estável, íntegra e coerente.

$\S 1^{\circ} \mathrm{Na}$ forma estabelecida e segundo os pressupostos fixados no regimento interno, os tribunais editarão enunciados de súmula correspondentes a sua jurisprudência dominante.

$\S 2^{2}$ Ao editar enunciados de súmula, os tribunais devem ater-se às circunstâncias fáticas dos precedentes que motivaram sua criação. ${ }^{7}$

\subsection{Ratio decidendi (ou holding) e obiter dictum}

Muito se diverge acerca do que se entende como a ratio decidendi dos precedentes. Há divergência, inclusive, no que tange a abrangência da ratio decidendi e do holding, na medida em que, para alguns, este é mais abrangente do que aquele. Neste trabalho, consideram-se sinônimos a ratio e o holding, seguindo o entendimento de Patrícia Perrone, Fredie Didier, Celso de Albuquerque Silva e outros.

Fredie Didier et al estabelecem como sendo a ratio decidendi "os fundamentos jurídicos que sustentam a decisão; a opção hermenêutica adotada na sentença, sem a qual a decisão não teria sido proferida como foi.” (Didier Jr. et al, 2016, p. 456). Já Patrícia Perrone conceitua que "constitui a norma extraída do caso concreto que vincula os tribunais inferiores" (Mello, 2008, p. 118).

Ainda sobre o conceito da ratio, temos:

A ratio decidendi é também chamada, em solo brasileiro, de motivo determinante de uma decisão. O motivo determinante, entendido como ratio, é a premissa sem a qual não se chegaria àquela decisão específica. É o motivo (ou são os motivos, já que se admite a existência de mais de uma ratio) suficiente e imprescindível à decisão que foi tomada (Marinoni, 2011, p.294).

$\mathrm{Na}$ mesma linha defendida por Marinoni, o conceito de Ronaldo Cramer mostra-se preciso ao afirmar que "a ratio decidendi são as razões necessárias e suficientes para a solução da causa ou de qualquer questão

7 Texto extraído do novo Código de Processo Civil, disponível no website https://www.planalto.gov.br/ccivil 03/_ato2015-2018/2015/lei/113105.htm, acessado em 10.11.2016. 
julgada pelo tribunal. Além disso, como enunciado, ratio decidendi deve ser compreendida como a norma jurídica criada pelo precedente. Por conseguinte, quando se identifica a ratio, identifica-se, por consequência, a norma a ser seguida em casos futuros." (Cramer, 2016, p. 106).

Já o obiter dictum são os argumentos que não possuem força obrigatória, embora sejam necessários à solução do caso concreto, são dispensáveis, e possuem apenas eficácia persuasiva.

Para melhor explicar, na Commom Law, buscou-se classificar os argumentos distinguindo os que generalizam dos circunstanciais. Nesse sentido, criou-se um código que contém os fundamentos definitivos para decidir (ratio decidendi) e os componentes marginais que só dizem respeito àquele caso concreto (obiter dictum).

Segundo Ronaldo Cramer, "o obiter dictum constitui todo e qualquer argumento dispensável para determinar a norma do precedente e que tem apenas o objetivo de ser ilustração, digressão, complementação ou reforço de argumentação das razões da decisão. São ditos de passagem, que nenhuma relevância tem para a decisão proferida.” (Cramer, 2016, p.107).

Segundo Conrado Hubner Mendes, a fronteira entre a ratio decidendi e o obiter dictum não é consensual e, dependendo da interpretação constitucional, da linguagem abstrata e do teor moral do caso concreto, essa fronteira será diferente e sempre haverá uma zona nebulosa em que não há consenso nenhum (Mendes, estudo dirigido, p. 2-3).

E é nessa zona nebulosa que se dá, também, a problemática de formação da ratio e, consequentemente, do precedente, questão que nos interessa em especial neste trabalho.

Voltando à discussão da interpretação jurídica para a problemática da identificação da ratio e partindo do princípio que o processo de interpretação é crucial para determiná-la, é preciso esclarecer que, na 
tomada de decisão jurídica, o que importa é encontrar o melhor resultado possível para cada caso, na medida em que as regras são atalhos para os resultados corretos.

Deixe-se claro, conforme já dito anteriormente, que há um tempo a tarefa do intérprete vai além de somente reproduzir ou explicitar o texto da norma. Isso porque falta um elemento para a interpretação ficar mais adequada: o fato ${ }^{8}$. Sua tarefa, portanto, é a constituição incessante de uma reformulação e adequação do texto legal às novas situações concretas (Marinoni, 2013, p. 115).

Ao final da interpretação do texto, da norma e dos fatos jurídicos relevantes para o caso concreto, a norma jurídica não se torna individual e concreta, apenas torna-se possível ser-lhe subsumido o caso mediante uma norma de decisão (em regra, individual e concreta) (Neves, 2013, p. 8).

Nessa linha, conclui-se que, além da interpretação da lei poder gerar múltiplas normas de limites indeterminados (o que por si só já fundamenta o sistema de precedentes), as decisões judiciais também não anunciam normas concisas e didáticas. E é nesse sentido que, ao adotar um sistema de precedente, para tentar minimizar a ampla variedade de interpretações, caímos em outro problema, qual seja, a determinação da ratio decidendi decorrente da interpretação da decisão dada pelo juiz naquele específico caso concreto em análise.

Infelizmente, raras às vezes, o tribunal, ao proferir uma decisão, determina de forma clara e específica a ratio, gerando, assim, muita controvérsia para sua identificação posterior. Isso acontece, segundo Noel Struchiner et al, porque um tribunal pode acabar, ao longo de uma única decisão i) formulando ratios diferentes, o que leva à insegurança do

\footnotetext{
${ }^{8}$ A introdução do fato na tarefa interpretativa entre o texto e a norma é um ponto crucial para se entender a formação e aplicação do precedente, uma vez que sem o fato jurídico relevante, não será possível identificar os casos semelhantes e suas teses jurídicas. Marcelo Neves muito bem destaca essa triangulação entre texto-norma-fato, conforme exposto no próximo capítulo.
} 
intérprete da sua versão final; ii) não estabelecendo uma ratio clara, com receio das consequências de tal decisão para casos inovadores; e iii) ao elaborar os votos individuais, formular várias rationes, ao invés de uma única ratio (Struchiner et al, 2016, p. 126).

Ademais, ainda há a possibilidade de ocorrer um vício de atividade que consiste na inexistência de ratio num precedente. Ronaldo Cramer, seguindo o entendimento de Lucas Buril de Macedô, explica que essa situação se dá sob duas hipóteses: “(a) por deficiência de fundamentação; e (b) por ausência de fundamento vencedor." (Cramer, 2016, p.106).

Assim, para aplicar o precedente, mesmo que o tribunal não tenha identificado claramente a ratio de pronto, o intérprete deverá encontrá-la por algum outro meio e, para isso, deverá driblar as complexidades da linguagem que é, na sua maioria, vaga e ambígua, bem como a própria fragilidade da atividade racional de determinação do sentido de um texto, além da interpretação e valoração do novo fato em análise.

Patrícia Perrone explica que a fundamentação da decisão é determinante para a identificação do nível de generalidade de cada fato aplicado no enunciado vinculante, uma vez que a força normativa do precedente emanará do que será descrito acerca do que decidiu, e não da própria decisão (Mello, 2008, p. 130). Estudos mais recentes e precisos acerca do precedente judicial feitos por Cramer, concluem que o que vincula não é a ementa, muito menos o dispositivo de uma decisão, mas sim a norma extraída da interpretação da fundamentação, em que se identifica as teses jurídicas utilizadas e os fatos jurídicos relevantes.

Fredie Didier Jr. et al, no mesmo sentido, afirmam que são as razões de decidir que irão operar a vinculação dos precedentes. Pra isso, extrair-seá uma regra geral (que pode ser aplicada a outras situações semelhantes) por meio de indução, em que só se pode considerar como tal (ratio 
decidendi), a norma que, apesar de partir do caso concreto, pode ser universalizada (Didier Jr. et al, 2016, p. 460).

Noel Struchiner et al, sobre a identificação da ratio, entendem que existe um procedimento comum a ser seguido. Esse procedimento baseia-se na seguinte premissa: a ratio é a regra geral, que em conjunto com os fatos do caso concreto, levarão à conclusão do tribunal, ou seja, a regra geral incluída no silogismo incompleto (no lugar da premissa maior) garante sua justificação interna (Struchiner et al, 2016, p. 125-127) .

Patrícia Perrone, Fredie Didier et al e Ronaldo Cramer, em suas obras, destrincham os métodos existentes de identificação da ratio (p. 461463; 130-145 e 109-113, respectivamente). Entretanto, Noel Struchiner et al, aponta para a problemática que importa para o presente: mais de uma norma é capaz de cumprir a função da ratio decidendi e a partir dessa pluralidade surgem regras mais amplas, regras nem tão amplas e nem tão estreitas (que, na teoria, seria o ideal) e regras mais estreitas.

Para demonstrar tal dificuldade, tem-se o exemplo do caso Riggs v. Palmer, em que o próprio neto envenena seu avô para ficar com a herança. O tribunal, ao decidir tal caso, articulou a seguinte norma geral que the serviu como razão para decidir sobre os demais casos de direito sucessório: "ninguém tem permissão de lucrar a partir da sua própria fraude ou tirar vantagem do próprio ato ilícito, ou adquirir propriedade a partir do próprio crime" (Struchiner et al, 2016. p. 125-126).

Para chegar a essa decisão, Noel e Fábio P. Shecaira, afirmam que:

[...] supondo que seja possível retratar a argumentação do tribunal como tendo no seu centro um silogismo jurídico, a ratio é a norma geral que, colocada no lugar da premissa maior, garantiria a justificação interna do silogismo. Em Riggs v. Palmer, o tribunal parece ter tomado a decisão com base no seguinte silogismo. Silogismo de Riggs

1. Ninguém tem permissão de adquirir propriedade a partir do próprio crime.

2. Palmer matou o avô com objetivo de assegurar sua herança. Logo, 
3. Palmer não tem permissão de receber a herança.

Suponha, no entanto, que o tribunal de Riggs v. Palmer não tivesse formulado a premissa maior claramente. Suponha, então, que, depois de ler a decisão, só fossemos capazes de identificar os seguintes elementos do silogismo usado pelo tribunal:

1. -

2. Palmer matou o avô com o objetivo de assegurar sua herança.

Logo,

3. Palmer não tem permissão de receber a herança.

[...] O problema é que mais de uma norma é capaz de cumprir essa função, por exemplo: 1) ninguém tem permissão de adquirir propriedade a partir do próprio crime (essa é a norma, bastante ampla, que de fato foi usada em Riggs v. Palmer); 2) ninguém tem permissão de adquirir propriedade a partir de crime doloso; 3) ninguém tem permissão de adquirir uma herança a partir do crime doloso contra o testador; 4) ninguém tem permissão de adquirir herança a partir de homicídio doloso contra o testador. Qualquer uma dessas normas cobriria o caso de Palmer e, portanto, garantiria a justificação interna do silogismo incompleto acima.

[...] Para falar a verdade, a lista do parágrafo anterior poderia ser estendida para incluir normas ainda mais específicas. Por exemplo: 5) ninguém tem permissão de adquirir herança a partir de homicídio contra o testador sendo o testador seu parente; 6) ninguém tem permissão de adquirir uma herança a partir de homicídio contra o testador sendo o testador seu avô; e assim por diante." (grifo meu) (Struchiner et al, 2016, p.127-128)

Nesse sentido, pecar pelo excesso de amplitude, tanto pecar pelo excesso de estreiteza é perigoso, devendo ser usado o equilíbrio entre os extremos. A parcimônia é uma das maiores preocupações dos juízes ao formular uma "premissa maior". E aqui, chega-se ao ponto crucial: a dificuldade de se estabelecer esse tipo de norma sem esbarrar nas controvérsias de natureza substantiva da linguagem jurídica. É neste ponto que o estudo da filosofia da linguagem aparece como crucial. 


\section{A indeterminação da linguagem}

\subsection{Filosofia pragmática da linguagem}

Não podemos negar a importância e influência da filosofia da linguagem para o esclarecimento de paradoxos conceituais no âmbito jurídico. Como esclarece Rachel Nigro, "a filosofia da linguagem e a guinada pragmática constituem a base filosófica que sustentam as doutrinas de apelação pós-positivista e nos oferece uma maneira diferente de pensar o direito em sua relação com a justiça, o poder e a moral" (Nigro, 2009, p. 206).

A fim de analisar a própria linguagem, bem como seu processo de significação, a filosofia da linguagem ganha importância no século XIX por meio de duas correntes: a analítica e a pragmática. A corrente analítica estuda a linguagem ideal e a corrente pragmática estuda a linguagem ordinária em seu uso concreto (Nigro, 2009, p. 178).

No contexto da filosofia pragmática, abandona-se a visão essencialista da linguagem, a qual defendia que as palavras tinham uma representatividade natural com a realidade (entre signo e objeto) para dar espaço à uma visão mais ampla que convencionou-se chamar de pragmática 9 .

A tradição filosófica do essencialismo linguístico de que há apenas um único e verdadeiro significado das expressões de linguagem e que o termo precisa de uma referência no mundo para existir, torna-se obsoleta

\footnotetext{
${ }^{9}$ O termo "pragmática" provém de uma classificação proposta por Morris em 1938 e adotada por diversos pensadores da linguagem, tanto da vertente analítica como da ordinária. Considerando a linguagem humana como um conjunto de signos, Morris divide o fenômeno da significação em três áreas distintas: sintaxe, semântica e pragmática. Dentro dessa tipologia, a pragmática é definida como a parte da semiologia que estuda a relação entre os signos e seus usuários. Enquanto a sintaxe estuda apenas a relação entre os signos, e a semântica restringe-se a investigar a relação entre os signos e o mundo, o estudo da linguagem sob o ponto de vista pragmático pretende dar conta da experiência concreta da linguagem, do contexto e dos múltiplos usos da linguagem cotidiana. (NIGRO, tese de doutorado, 2007, p. 19).
} 
quando se chega à conclusão que essas relações são convencionais e não naturais (Santiago, 2010, p. 293-294) ${ }^{10}$. Convencionais porque passa a se entender que as palavras não tem uma essência definitiva, ou seja, não mentalizamos e procuramos objetos reais correspondentes, o que acontece são cristalizações de determinadas crenças e convenções. O uso é o critério capaz de definir o significado dos atos de fala nos determinados contextos ou jogos de linguagem.

Essa virada linguístico-pragmática busca estudar a linguagem ordinária em ação, em seu pleno funcionamento, determinando o sentido das proposições por meio de uma nova unidade de significação, o ato de fala. O estudo da linguagem pragmática baseia-se, portanto, na experiência concreta entre os falantes que dela participam, do contexto que estão inseridos e dos seus múltiplos usos (Nigro, 2009, p. 180-183).

E é essa Filosofia da Linguagem ordinária que revoluciona a forma de se fazer Filosofia do Direito. Wittgenstein e Austin contribuem para essa evolução na medida em que ultrapassam a primazia da linguagem descritiva de antes por meio da noção de jogos de linguagem e da ideia de atos de fala.

Nesse sentido:

De acordo com Wittgenstein das Investigações filosóficas - que rompe com a teoria pictórica do significado - e seus discípulos de Cambridge, assim como os filósofos da linguagem de Oxford, a linguagem descritiva não tem primazia sobre outros usos da linguagem. Aliás, são eles que apontam para o fato de que a linguagem pode apresentar diversos usos, todos significativos.

A noção de jogos de linguagem de Wittgenstein entra em cena para mostrar que a linguagem funciona como uma caixa de ferramentas que pode ser usada para realização de várias atividades, como, por exemplo, contar piadas, pedir, ordenar, descrever, etc. A linguagem não é sempre uma representação dos fatos do real, mas sim uma atividade, capaz de exercer uma pletora de funções divergentes. Assim como ocorre com os diversos jogos, a miríade de usos da linguagem não apresenta uma única propriedade ou conjunto de propriedades necessárias e suficientes, que perpassam toda e qualquer instância do emprego

\footnotetext{
${ }^{10}$ Segundo a tradição filosófica do essencialismo linguístico (que remonta ao Crátilo de Platão), há um "verdadeiro" e "único" significado das expressões da linguagem, que deve ser captado investigando-se uma misteriosa realidade não empírica. Carnap a chamou de "concepção mágica da linguagem" e Kantorowicz de 'realismo verbal'. (Nigro, 2009, p. 17).
} 
linguístico, mas está relacionada por semelhanças de família, semelhanças que se envolvem e se cruzam como em um retrato de família.

A ideia de atos de fala, inicialmente desenvolvida por Austin, caminha na mesma esteira dos jogos de linguagem. A linguagem é melhor compreendida como forma de ação no mundo do que como uma maneira de descrever o mundo. $\mathrm{O}$ ato de fala constatativo é apenas um ato ilocucionário [...] possível, entre vários outros. O ponto é que existe uma pluralidade de funções, atividades ou práticas linguísticas divergentes. É um erro grave e um excesso de simplificação imaginar que a única atividade plausível para a linguagem é descrever o mundo. (grifo meu) (Struchiner, 2006, p. 336).

O jogo de linguagem de Wittgenstein, portanto, busca demonstrar que a linguagem funciona como um conjunto de atividades linguísticas (emprego se signos, contexto, gestos, fala, ambiente, etc.) situada cultural e historicamente e dependerá do seu uso para ser determinada. Enquanto o ato de fala de Austin é a ideia de que a linguagem é uma verdadeira ação, bem como toda ação é realizada através do dizer ${ }^{11}$.

Esses filósofos (e outros que desenvolveram a filosofia da linguagem ordinária) chamam atenção para os contextos que em que usamos a linguagem, pois são esses diferentes contextos que demonstram que não existe apenas um único modelo de emprego ao qual ela deve atender.

\subsection{Textura aberta da linguagem}

Uma das maiores contribuições da Filosofia da Linguagem para o direito é a noção de textura aberta desenvolvida por Friedrich Waismann, ao dizer que compreendemos afirmações ordinárias, sem exigir nenhuma verificação, porque conhecemos seus termos e que tal verificação (questionamento) ocorrerá quando as afirmações tiverem combinações de termos que nunca foram utilizadas, carecendo, assim, de uma explicação. Com isso, Waismann pretende dizer que surge espaço para dúvida sobre os significados das afirmações, uma vez que os conceitos empíricos possuem

\footnotetext{
${ }^{11}$ Austin divide os atos de fala em ato locucionário, ato ilocucionário e ato perlocucionário. Sobre tal distinção, indica-se a leitura do verbete do Noel Struchiner sobre Filosofia da Linguagem, p. 335.
} 
uma "incompletude essencial", ou seja, não apresentam uma definição exaustiva.

A partir do conceito de "hipótese" de Wittgenstein, Waismann chega à conclusão de que, tendo em vista que uma única hipótese admite inúmeras verificações independentes, elas jamais poderão ser absolutamente certas. Logo, nenhuma linguagem está preparada para todas as possibilidades e a afirmação empírica não poderá ser verificada de forma conclusiva, em decorrência da textura aberta da linguagem.

$\mathrm{Na}$ hermenêutica jurídica chamamos de textura aberta a vagueza e a ambiguidade dos termos e da linguagem ordinária. Segundo o professor Noel Struchiner, Hart foi o responsável por trazer essa discussão para a análise da linguagem jurídica. Mais precisamente, aponta em seu verbete que:

\begin{abstract}
Vários termos que utilizamos na nossa linguagem são potencialmente vagos. Hart é o responsável por fazer a transposição dessa discussão para a análise das regras jurídicas. Como as regras contém termos que possuem uma textura aberta, então as regras jurídicas são potencialmente vagas. Sempre é possível surgir um caso que cai na região de penumbra do significado dos termos empregados na norma. A textura aberta da linguagem tem relevância para a prática jurídica, uma vez que a decisão da aplicação da regra em um caso concreto muitas vezes recai na questão sobre o significado ou abrangência de um termo geral classificatório encontrado na regra. (grifo meu) (Struchiner, 2006, p. 336).
\end{abstract}

Para exemplificar a dificuldade de se aplicar uma regra na prática, quando a questão recai sobre o significado e a abrangência de um termo geral classificatório, Hart utiliza a regra clássica sobre a proibição de entrada de veículos no parque. A indeterminação sobre as palavras "veículo" e "parque" causam controvérsias, pois, se pode entender, ao se deparar com a regra pela primeira vez, que veículo abarca carros de passeio, patinete, skate, ou se se limita a parques urbanos, ou se se estende a parques de preservação natural, etc. Assim, ao se tomar uma decisão sobre qual 
tratamento deve-se dar aos sentidos e abrangência dos termos, torna-se a regra mais clara para os próximos casos (Struchiner, 2006, p.109).

Muito embora Hart tenha sido o precursor, Noel aponta Robert Alexy como um dos filósofos que mais menciona, em seus trabalhos sobre argumentação jurídica, a problemática da textura aberta e a vaguidade na linguagem jurídica, sem diferenciá-las, mas apontando em que situações elas se destacam:

[...] no seu livro The Argument from Injustice, Alexy afirma:

"Conforme coloca Hart, todo direito positivo possui uma textura aberta. Existem algumas razões para isso. Com especial significado pode-se destacar a imprevisibilidade da linguagem legal, a possibilidade de conflitos normativos, a ausência de uma norma para servir como base para a decisão, e, em alguns casos, a possibilidade de se tomar uma decisão contrária a uma leitura literal da regra. Pode-se se falar aqui, de uma "região aberta" do direito positivo, que pode ser mais ou menos ampla, mas que existe em todo sistema jurídico. Um caso que cai sob a região aberta vai ser chamado de "caso duvidoso" (ALEXY, 2003, p. 68-69).” (grifo meu) (Struchiner, 2005, p.107).

Cumpre salientar que Noel diferencia textura aberta de vaguidade. Para ele, a textura aberta representa sempre uma potencial vaguidade, que nunca será sanada, já que sempre poderão surgir hipóteses que não foram previstas, gerando dúvidas acerca do que deve ser aplicado. Já a vagueza $^{12}$ pode ser corrigida por meio do fornecimento de regras, em que o que não se sabe é quantificar, nem quais, nem como as propriedades devem ser combinadas para que o conceito seja reconhecido e aplicado.

Para melhor compreensão do termo de vagueza, o professor Noel Struchiner cita dois exemplos: o conceito de careca (quantos fios de cabelo tenho que perder para ser considerado careca?), para a vagueza de grau, e o conceito de xadrez (ao mudar as regras, fazendo uma combinação diferente

\footnotetext{
${ }^{12}$ Sobre o processo de formação das regras, ao explicar o fenômeno da generalidade na teoria das regras prescritas de Schauer, Noel as divide em subinclusivas e sobreinclusivas. Sobre seus conceitos, ensina que, respectivamente, "é o fato de as regras prescritivas incorporarem mais casos do que deveriam, ou deixarem de incorporar casos que deveriam incorporar para concretizar suas justificações subjacentes, que torna o direito, ou melhor, a prática jurídica, um terreno de opções ou escolhas" (Rodriguez, 2010, p. 104).
} 
delas, ainda será o mesmo jogo?), para o conceito de vagueza combinatória. (Struchiner, 2006, p. 117-118).

Destaca-se, pois, que a flexibilidade, em grau moderado, trazida pela que a vaguidade da linguagem jurídica ao ordenamento jurídico, é essencial para que esse seja justo e equânime.

Nessa mesma linha, Genaro Carrió explica a vagueza das palavras por meio de uma metáfora com um feixe de luz. No foco de intensidade luminosa, teríamos os exemplos típicos, os quais não se tem dúvida de qual palavra é aplicável. Na zona de escuridão, caem todos os casos em que não se tem dúvida de que não é aplicável. A zona de trânsito entre a luminosidade e a escuridão é gradual, em que há uma penumbra sem limites precisos. E é nessa zona que não tem começo nem fim definido que estão as palavras que usamos para refletir o mundo e a nós mesmos, com uma vaga aura de incerteza (Andrade, 2008, p. 462-463).

Há ainda quem cite a ambiguidade como um fator relevante da textura aberta. Segundo Nino, a ambiguidade é a possibilidade de um texto apresentar mais de um sentido, seja porque veio de uma "homonomia acidental", ou de uma "ambiguidade de processo-produto", seja por causa de divergência entre o sentido ordinário e técnico ou problemas de conexão sintática (Andrade, 2008, p. 459-474).

Hart, ao estender o fenômeno da textura aberta tanto aos termos linguísticos quanto às regras e às sentenças, admite a existência permanente de uma "penumbra de dúvida" que dificulta as possibilidades de concretização do direito. Nesses casos, o juiz não vai meramente "aplicar" a regra ao caso concreto, pois a situação pede uma elaboração intelectual mais complexa, qual seja, "interpretar" o direito, exercendo seu poder de 
discricionariedade $^{13}$ (Struchiner, 2006, p. 111). Para ele, é sob a aplicação dos precedentes (que criam normas a partir de uma interpretação jurídica) que será feito o controle social, uma vez que na sua aplicação que serão corrigidos os excessos das regras expressas em forma generalizada (Struchiner, 2001, p. 3-4).

\section{Como esclarece Struchiner:}

Vale lembrar que o interesse de Hart é mostrar como o direito é possível, isto é, como o direito pode fornecer pautas de conduta para casos futuros que possam ser obedecidas sem maiores problemas. A resposta que ele encontra é que o direito funciona porque toda regra tem um núcleo de certeza onde a maioria dos casos são encontrados e onde sabemos se ela deve ser aplicada ou não. Como, na maioria dos casos, a linguagem da regra é facilmente compreendida por todos, sem a necessidade de maiores explicações, então o direito é capaz de cumprir sua principal tarefa: guiar comportamentos futuros. Em outras palavras, é em função da existência de um núcleo de certeza nas regras que os critérios para existência do direito são preenchidos. (Struchiner, 2016, p. 113).

Dessa forma, o juiz, ao decidir no caso concreto a melhor interpretação da norma a ser aplicada, extrairá a ratio, já que é ela que torna a aplicação da regra mais clara e limitada aos casos futuros. Ao direito, a textura aberta é inevitável e até desejável, desempenhando uma função fundamental ao incorporar oscilações que a sociedade, o direito e a linguagem exigem. É ela, pois, que possibilita a escolha da extensão do escopo ou os termos gerais de cada regra, corrigindo (dentro do possível) as imprecisões diante de situações não previstas pelo legislador no momento de sua elaboração (Struchiner, 2002, p. 3). "A textura aberta de um termo geral permite que ele passe a englobar as novidades da vida." (Struchiner, 2005, p. 111).

Contudo, é preciso entender que certos limites semânticos só podem ser estabelecidos mediante uma situação fática concreta, mediante um contexto. Assumir a vagueza da linguagem e, consequentemente, dos textos

\footnotetext{
${ }^{13}$ Imperioso ressaltar que a discricionariedade não se confunde com a arbitrariedade, sendo aquela essencial para a constante evolução do direito em detrimento do engessamento social e temporal, enquanto esta indica uma parcialidade não desejável para o bom funcionamento do Direito.
} 
normativos, é entender que ambos são obras humanas passíveis de certo grau de indeterminação. Estranho seria admitir apenas interpretações e aplicações robóticas e mecanizadas para processos humanos e fatos concretos.

Com relação ao sistema de precedentes, não obstante a complexidade de se analisar as semelhanças fáticas necessárias e suficientes entre os casos passados e presentes para que a mesma decisão seja tomada (ou seja, seja aplicado o precedente), é a textura aberta dos termos que faz com que esse tipo de análise e aplicação ao caso concreto seja possível. Isso porque, ao estabelecer a ratio do precedente, se busca utilizar termos que sejam capazes de abranger todos os casos semelhantes com certas características específicas, de modo que os casos semelhantes possam ser contemplados pelo precedente e, ao mesmo tempo, a ratio não seja aberta demais a ponto de se tornar ineficaz.

Nas palavras de Hart:

\begin{abstract}
"A textura aberta do Direito significa que há, na verdade, áreas de conduta em que muitas coisas devem ser deixadas para serem desenvolvidas pelos tribunais ou pelos funcionários, os quais determinam o equilíbrio, à luz das circunstâncias, entre interesses conflitantes que variam em peso, de caso para caso. Seja como for, a vida do Direito traduz-se em larga medida na orientação, quer das autoridades, quer dos indivíduos privados, através de regras determinadas que, diferentemente das aplicações de padrões variáveis, não exigem deles uma apreciação nova de caso para caso. Este facto saliente da vida social continua a ser verdadeiro, mesmo que possam surgir incertezas relativamente à aplicabilidade de qualquer regra (quer escrita, quer comunicada por precedente) a um caso concreto. Aqui, na franja das regras e no campo deixado em aberto pela teoria dos precedentes, os tribunais preenchem uma função criadora de regras que os organismos administrativos executam de forma centralizada na elaboração de padrões variáveis [...] [Hart, 1986:148-149]" (Andrade, 2008, p. 466).
\end{abstract}

Ao se admitir a textura aberta da linguagem jurídica, admite-se, como dito, a importância da atuação do intérprete. $E$ isso não significa que as soluções do caso serão arbitrárias. A textura aberta da linguagem jurídica em conjunto com a necessidade de se diminuir a arbitrariedade ou a 
irracionalidade nas decisões pavimentam o terreno para a aplicação da teoria da argumentação. E é justamente na adoção de um sistema de precedentes e, consequentemente, de identificação da ratio da decisão, que o Judiciário é capaz de impedir a criação desenfreada de uma multiplicidade de normas que gerariam insegurança e desigualdade diante da discricionariedade de escolha interpretativa (Marinoni, 2013, p. 118 e Noel, 2006, p. 337).

\subsection{Diferença entre texto e norma}

Acerca da dificuldade de identificação da ratio apontada acima, é importante abordar o tema da diferença entre texto e norma, tendo em vista que as normas não emanam apenas das regras positivadas pelo legislador, mas sim de um sistema integrado de dispositivos (regras e princípios), este por sua vez recheado de contradições, lacunas, ambiguidades, vagueza, etc.

Partindo do princípio de que o significado de um texto é algo que depende do seu uso e da interpretação em consonância com o sistema e com o contexto em que está inserido, pode-se concluir que os significados modificam-se com o tempo, no espaço e de acordo com as controvérsias jurídicas. Texto, portanto, é o "signo gráfico ou o suporte material"14 da norma, enquanto a norma é o texto normativo interpretado de forma sistêmica (Ávila, 2010, p. 32).

Nino Santiago destaca a importância da interpretação de forma sistêmica:

A intenção do legislador não é um critério decisivo para atribuir significado às suas palavras, tendo preferência sobre ele a determinação de como as palavras seriam razoavelmente interpretadas por seus destinatários e as considerações sobre a relação que a norma em questão deve ter com outras que integram o sistema jurídico.

Assim, não é de todo exagerado afirmar que, no direito legislado, os juízes estão vinculados não por um conjunto de normas, mas por uma série de orações cujo

\footnotetext{
${ }^{14}$ SGARBI, Adrian. Introdução à teoria do direito, Marcial Pons., 2013, p. 55.
} 
significado é atribuído de acordo com certas regras semânticas e sintáticas, quer o próprio legislador as tenha considerado ou não. (Santiago, 2010, p. 291).

É justamente no fato de as normas serem “construídas” a partir dos textos e contextos que os intérpretes autorizados podem jogar com as possibilidades de interpretação e fazer usos diferentes das expressões linguísticas escolhidas pelo legislador, concretizando a norma criada a partir do caso concreto (Ávila, 2010, p. 32). Conforme foi dito anteriormente, a linguagem não é algo pré-dado, como pensavam os essencialistas, mas sim algo que se constitui e se recria de acordo com o seu uso, com o contexto e seus interlocutores, como muito bem destaca Humberto Ávila:

O intérprete não atribui "o" significado correto dos termos legais. Ele só constrói exemplos do uso da linguagem ou versões do significado - sentidos -, já que a linguagem nunca é algo pré-dado, mas algo que se concretiza no uso, ou melhor, como uso. (Ávila, 2010, p.32).

Neste ponto, merece destaque um fator importante para a distinção entre texto e norma e que é frequentemente menosprezado pelos teóricos do direito: o fato jurídico. Marcelo Neves, por sua vez, aponta a necessidade de se distinguir três elementos essenciais da interpretação/aplicação jurídica: o texto normativo, a norma e o fato jurídico, os quais ele chama, respectivamente de significado, significante e referente (Neves, 2013, p. 4).

Utilizando-se de uma metáfora da mitologia grega, a Hidra de Lerna (uma serpente de muitas cabeças), Neves compara as hidras (as inúmeras cabeças que nascem) com as possíveis interpretações dos textos mais abertos como os princípios, enquanto as regras seriam o tição capaz de cauterizar suas cabeças e, consequentemente, fechar as possibilidades interpretativas abertas pelos textos principiológicos.

Para explicar a necessidade de se formar os textos, assume, também, que a norma e o fato possuem dois problemas: a ambiguidade e a vagueza. Marcelo Neves considera que para haver a superação da ambiguidade é 
imprescindível que se interprete o texto, enquanto que para superar a vagueza, deve-se aplicar a norma ao fato, desenvolvendo um processo de concretização da mesma.

Vejamos:

[...] A esse respeito, cabe considerar o problema da ambiguidade (na conotação) e vagueza (na denotação) do texto normativo. A primeira significa que as disposições, em particular as constitucionais, não são unívocas, ou seja, ao menos prima facie, podem ser-lhes atribuídos mais de um significado. Isso significa a possibilidade de que mais de uma norma possa ser extraída de uma mesma disposição normativa, ou, mais precisamente, atribuída a esta. Por sua vez, a vagueza refere-se à imprecisão em definir quais são os referentes da norma, ou seja, a indeterminação dos limites do âmbito dos fatos jurídicos e respectivos efeitos jurídicos que estão previstos na disposição normativa e, pois, na norma. [...] Precisa-se, portanto, de uma "interpretação dos fatos" para que se supere a vagueza para o caso concreto e a norma possa ser aplicada.

Para superação da ambiguidade de disposições normativas é fundamental a interpretação do respectivo texto. Para a superação da vagueza e a aplicação normativa a um caso concreto, vai-se além, desenvolvendo-se um amplo processo seletivo de concretização da norma. Esclareça-se, porém, que, com o final da concretização, a norma jurídica não se torna individual e concreta, apenas tornase possível ser-lhe subsumido o caso mediante uma norma de decisão (em regra, individual e concreta). A concretização implica, portanto, a interpretação tanto do texto da norma quanto dos fatos jurídicos relevantes para o caso [...] (grifo meu) (Neves, 2013, p. 7 e seguintes).

Ademais, na relação entre normatização e concretização (legislativo e judiciário), ou seja, entre texto e norma, existe uma dupla contingência. Isso significa que o legislativo atribui um sentido ao texto normativo (uma pretensão de limitar e determinar seu conteúdo), o qual precisa ser compreendido pelo judiciário. Esse último, no entanto, pode equivocar-se e, a partir do que compreendeu sobre o sentido atribuído pelo legislativo, atribuirá um novo sentido próprio (Neves, 2013, p. 10-11).

É nessa perspectiva que entra a necessidade de se limitar certos entendimentos, extraindo-se a ratio da decisão, a fim de construir um entendimento coerente para os casos semelhantes. A existência de falhas na comunicação é sempre possível, logo, há que se identificar um núcleo mínimo (a ratio) entre os textos interpretados e as normas extraídas dos 
primeiros julgados (precedentes) para não gerar injustiças e garantir a previsibilidade do sistema. 


\section{O instituto dos precedentes no Novo Código de Processo Civil}

Antes de se adentrar na análise do instituto dos precedentes sob a ótica do novo Código de Processo Civil, é preciso destacar que não se tem a pretensão de fazer uma análise processual, importando mais uma apresentação geral dos diplomas legais, voltando o estudo para a problemática linguístico-interpretativa de sua formação e aplicação.

Os artigos 489, 926 e 927 do referido diploma legal formalizam o entendimento de que texto e norma não se confundem e que, para a formação de normas, deve-se, necessariamente, haver a interpretação do texto que carrega consigo termos cuja textura pode ser aberta. Esse giro hermenêutico faz com que os criadores do novo Código de Processo Civil se preocupem com o controle da liberdade interpretativa dos julgadores, com a garantia da igualdade de todos perante a ordem jurídica, bem como com a segurança jurídica.

Em termos gerais, o art. 927 do CPC define quais são os precedentes com força vinculante e estabelece algumas regras sobre aplicação, modificação e publicidade do precedente; o art. 926 do CPC estabelece normas gerais sobre precedentes e afirma que os tribunais devem manter a jurisprudência estável, íntegra e coerente; e o art. 489 exige que o juiz, ao aplicar um precedente, identifique seus fundamentos determinantes e demonstre que o caso se encaixa nesses fundamentos, e que ao deixar de seguir um precedente, demonstre a distinção com o caso concreto ou a superação entendimento. 


\subsection{Os dispositivos legais pertinentes}

Muito se discutiu, na elaboração do Novo Código de Processo Civil, se o ordenamento deveria continuar tratando a jurisprudência como um argumento apenas persuasivo ou se deveria adotar o sistema de precedentes vinculantes. Pelo histórico de formação do art. 927 do CPC, pode-se concluir que o Legislador teve a intenção de trazer para o ordenamento jurídico brasileiro um rol de precedentes vinculantes ${ }^{15}$ (Cramer, 2016, p. 181-183). Existem, entretanto, cinco correntes ${ }^{16}$ que discutem se o rol é mesmo vinculante ou não e, na opinião dos autores aqui selecionados, assiste razão à primeira delas que defende o efeito vinculante do art. 927 do CPC.

Fato é que, conforme exposto no parágrafo anterior, não se pode deixar de lado a vontade do Legislador. Mesmo que esse produza um texto que se transforma em norma pela interpretação, o texto não é constituído de forma autônoma e livre de intenções. Analisando o processo criativo do art. 927 do $\mathrm{CPC}^{17}$, é nítido que o Legislador teve a intenção clara de dar eficácia vinculante ao mesmo, e tal intento não pode ser desconsiderada pelo intérprete.

\section{Ao texto legal:}

Art. 927. Os juízes e os tribunais observarão: I - as decisões do Supremo Tribunal Federal em controle concentrado de constitucionalidade;

\footnotetext{
${ }^{15}$ Sobre o histórico de formação do art. 927 na elaboração do Novo Código de Processo civil e suas diferentes versões de redações, indica-se a leitura das páginas 176-183 do livro Precedentes Judiciais - entre teoria e dinâmica, do professor Ronaldo Cramer.

${ }^{16}$ A primeira defende que existe um rol de precedentes vinculantes, e não meramente vinculativos. A segunda prevê que o que dá força vinculativa ao art. 927 do CPC é a previsão de reclamação. A terceira alega que a eficácia vinculante decorre do próprio ordenamento jurídico e não pela aplicação do art. 927do CPC. A quarta defende que o referido artigo é inconstitucional, já que o efeito vinculante deve ser feito apenas pela Constituição Federal. Já a quinta corrente, por sua vez, entende que somente os tribunais podem emitir precedentes, sendo esses todos, inclusive os previstos no art. 927 do CPC, vinculantes. Ronaldo Cramer explica cada uma dessas correntes e as refuta nas páginas 183-192 de sua obra (Precedentes Judiciais - teoria e dinâmica).

${ }_{17}$ Sobre o histórico do art. 927 do NCPC, indica-se a leitura das páginas 176-183 da obra Precedentes Judiciais - teoria e dinâmica de Ronaldo Cramer.
} 
II - os enunciados de súmula vinculante;

III - os acórdãos em incidente de assunção de competência ou de resolução de demandas repetitivas e em julgamento de recursos extraordinário e especial repetitivos;

IV - os enunciados das súmulas do Supremo Tribunal Federal em matéria constitucional e do Superior Tribunal de Justiça em matéria infraconstitucional; $\mathrm{V}$ - a orientação do plenário ou do órgão especial aos quais estiverem vinculados. $\S 1^{\circ}$ Os juízes e os tribunais observarão o disposto no art. 10 e no art. $489, \S$ 1o, quando decidirem com fundamento neste artigo.

$\S 2^{\circ}$ A alteração de tese jurídica adotada em enunciado de súmula ou em julgamento de casos repetitivos poderá ser precedida de audiências públicas e da participação de pessoas, órgãos ou entidades que possam contribuir para a rediscussão da tese.

$\S 3^{\circ} \mathrm{Na}$ hipótese de alteração de jurisprudência dominante do Supremo Tribunal Federal e dos tribunais superiores ou daquela oriunda de julgamento de casos repetitivos, pode haver modulação dos efeitos da alteração no interesse social e no da segurança jurídica.

$\S 4^{\circ} \mathrm{A}$ modificação de enunciado de súmula, de jurisprudência pacificada ou de tese adotada em julgamento de casos repetitivos observará a necessidade de fundamentação adequada e específica, considerando os princípios da segurança jurídica, da proteção da confiança e da isonomia.

$\S 5^{\circ}$ Os tribunais darão publicidade a seus precedentes, organizando-os por questão jurídica decidida e divulgando-os, preferencialmente, na rede mundial de computadores. ${ }^{18}$ (grifo meu)

Sobre a redação do referido artigo, Cramer faz algumas observações pontuais, as quais corroboram com o entendimento de que não há como desprezar o esforço legislativo de dar eficácia vinculante aos precedentes:

A redação do caput do art. 927 do NCPC, ao dispor que "juízes e tribunais observarão", tem a clareza semântica difícil de superar. O verbo observar, nesse caso, não tem o sentido de "olhar com atenção", mas o de "cumprir" ou "respeitar". Diante do que está escrito no texto, não há maneira mais inequívoca de se estabelecer a eficácia vinculante dos precedentes.

Além do mais, o art. 927 do NCPC, tanto no caput, e os parágrafos, encontram-se estruturado a partir da premissa de que os precedentes ali relacionados são vinculantes. $O$ maior exemplo disso, como já explicado, constitui o seu $\S^{\mathbf{0}}$, que exige contraditório prévio e fundamentação específica na aplicação dos precedentes arrolados pelo caput. Essa regra só tem razão de ser se, evidentemente, os precedentes do caput forem considerados vinculantes. Do contrário, ela não faz o menor sentido. (grifo meu) (Cramer, 2016, p. 191).

Ainda, vale ressaltar que a eficácia vinculante do precedente é uma eficácia interna do Poder Judiciário (ao tribunal que o produziu e aos

18 Texto extraído do novo Código de Processo Civil, disponível no website https://www.planalto.gov.br/ccivil_03/_ato2015-2018/2015/lei/113105.htm, acessado em 10.11.2016. 
demais órgãos a ele subordinados), a qual abrange apenas a ratio decidendi, e não tem como base seu dispositivo. Além disso, o rol do referido artigo não é taxativo e é possível chegar a essa conclusão porque, além de o próprio CPC prever outros precedentes vinculantes que não estão inseridos expressamente no art. 927 do CPC (como, por exemplo, a decisão do Supremo que declara inexistência de repercussão geral para todos os recursos extraordinários com a mesma matéria do art. $1035, \S 8^{\circ}$ do $\mathrm{CPC}$ ), não há nenhuma outra norma federal que proíba dar eficácia vinculante a outro tipo de precedente (Cramer, 2016, 192).

Sobre o caráter exemplificativo do art. 927 do CPC, Marinoni corrobora com o entendimento acima, alegando que basta analisar as normas constitucionais que atribuem aos Tribunais Superiores a função de outorga de unidade ao direito constitucional e infraconstitucional. Para ele, tal artigo é até desnecessário, pois consiste em apenas uma lembrança de que alguns precedentes, além de súmulas e controversas decisões tomadas em incidentes de natureza erga omnes, deverão ser observados por juízes e tribunais.

Também é pertinente analisar o art. 926 do CPC, in verbis:

Art. 926. Os tribunais devem uniformizar sua jurisprudência e mantê-la estável, íntegra e coerente.

$\S 1^{\circ} \mathrm{Na}$ forma estabelecida e segundo os pressupostos fixados no regimento interno, os tribunais editarão enunciados de súmula correspondentes a sua jurisprudência dominante.

$\S 2^{2}$ Ao editar enunciados de súmula, os tribunais devem ater-se às circunstâncias fáticas dos precedentes que motivaram sua criação. ${ }^{19}$ (grifo meu)

Dele podemos extrair quadro deveres importantes para os tribunais: uniformidade, estabilidade, integridade e coerência (Cramer, 2016, p. 124129). O dever de uniformidade significa uniformizar internamente o

19 Texto extraído do novo Código de Processo Civil, disponível no website https://www.planalto.gov.br/ccivil_03/_ato2015-2018/2015/lei/113105.htm, acessado em 10.11.2016. 
entendimento de seus órgãos fracionários, sem deixar que haja divergência de entendimento entre eles, para possibilitar a identificação da posição do tribunal. O dever de estabilidade significa, além de possuir precedentes e jurisprudência sólidos que assegurem o posicionamento do tribunal sobre certas questões, respeitar seus próprios precedentes e de tribunais superiores, bem como justificar de forma específica caso altere ou supere seus precedentes (art. 927, $\S 4^{\circ}$ do $\mathrm{CPC}$ ). Integridade, ainda, significa construir novos precedentes levando em consideração precedentes anteriores adotados pelo mesmo tribunal ou tribunal superiores, tal como as normas constitucionais de nosso ordenamento. Já a coerência significa a aplicação de precedentes somente às causas com identidade de tese jurídica e a justificação da decisão que opta por adotar ou não o precedente, conforme determinam os incisos V e VI do $§ 1^{\circ}$ do art. 489 do CPC.

Dessa forma, esses deveres possibilitam a construção e manutenção de um sistema de precedentes e consequentemente introduzem a adoção do stare decisis no ordenamento jurídico brasileiro (Barbosa, 2015, p. 53).

Ainda, merece atenção especial o art. 489 do CPC:

Art. 489. São elementos essenciais da sentença:

I - o relatório, que conterá os nomes das partes, a identificação do caso, com a suma do pedido e da contestação, e o registro das principais ocorrências havidas no andamento do processo;

II - os fundamentos, em que o juiz analisará as questões de fato e de direito;

III - o dispositivo, em que o juiz resolverá as questões principais que as partes lhe submeterem.

$\S 1^{\circ}$ Não se considera fundamentada qualquer decisão judicial, seja ela interlocutória, sentença ou acórdão, que:

I - se limitar à indicação, à reprodução ou à paráfrase de ato normativo, sem explicar sua relação com a causa ou a questão decidida;

II - empregar conceitos jurídicos indeterminados, sem explicar o motivo concreto de sua incidência no caso;

III - invocar motivos que se prestariam a justificar qualquer outra decisão;

IV - não enfrentar todos os argumentos deduzidos no processo capazes de, em tese, infirmar a conclusão adotada pelo julgador;

V - se limitar a invocar precedente ou enunciado de súmula, sem identificar seus fundamentos determinantes nem demonstrar que o caso sob julgamento se ajusta àqueles fundamentos; 
VI - deixar de seguir enunciado de súmula, jurisprudência ou precedente invocado pela parte, sem demonstrar a existência de distinção no caso em julgamento ou a superação do entendimento.

$\S 2^{\circ}$ No caso de colisão entre normas, o juiz deve justificar o objeto e os critérios gerais da ponderação efetuada, enunciando as razões que autorizam a interferência na norma afastada e as premissas fáticas que fundamentam a conclusão.

$\S 3^{\circ}$ A decisão judicial deve ser interpretada a partir da conjugação de todos os seus elementos e em conformidade com o princípio da boa-fé. ${ }^{20}$ (grifo meu)

Mas, antes de adentramos em sua análise, é preciso citar o princípio constitucional da obrigatoriedade de motivação das decisões judicias (disposto no art. 93, IX da Constituição Federal), o qual preconizava, até então, que a fundamentação da decisão judicial era direcionada ao julgado do caso concreto. Com o advento do art. 489 do novo Código de Processo Civil, esse princípio torna-se melhor explicitado como meio de conhecer as razões das decisões.

Isso porque, no sistema de precedentes, o julgado que criar a norma produzida pelo precedente deverá conter dois tipos de fundamentação: interna e externa ${ }^{21}$. A interna será para solucionar o caso concreto em comento e a externa para formulação da norma de caráter geral (Cramer, 2016, p. 134). Assim, a decisão judicial conterá a análise de todas as questões de fato e de direito pertinentes para a apreciação do caso, bem como todos os argumentos que expliquem os motivos considerados pela decisão para chegar à norma formulada (Cramer, 2016, p.135).

Passa-se a considerar que a decisão judicial deverá conter os elementos acima justamente para viabilizar e facilitar a identificação e aplicação do precedente, tendo em vista que a norma dele emanada encontra-se na fundamentação. Repita-se: a ratio não é a fundamentação, apenas está contida dentro dela, sem se confundir, também, com o dispositivo nem com a ementa. E aqui, volta-se à discussão sobre a

20 Texto extraído do novo Código de Processo Civil, disponível no website https://www.planalto.gov.br/ccivil_03/_ato2015-2018/2015/lei/113105.htm, acessado em 10.11.2016.

${ }^{21}$ Ronaldo Cramer chama esses dois tipos de fundamentação de discurso interno e discurso externo (Cramer, 2016, p. 134) 
dificuldade de se extrair a tese jurídica da norma do precedente. Não obstante essa dificuldade pode-se concluir que, sem uma fundamentação clara e um entendimento edificado, mais difícil será realizar tal extração da ratio (Cramer, 2016, p. 135-136).

Além de ser difícil, esta é uma tarefa que os operadores do direito brasileiro não estão familiarizados:

O profissional que lida com o sistema de justiça no Brasil não está acostumado a interpretar a fundamentação do julgado. Normalmente, seja em petições, seja em decisões, o julgado é citado por sua ementa ou ainda por sua conclusão. Dificilmente buscam-se argumentos da fundamentação para demonstrar determinado entendimento do tribunal. Mesmo na doutrina, é raro encontrar o caso concreto. Diante disso, com mais razão, impõe-se que, no mesmo sistema de precedentes aplicado ao Direito Processual Civil brasileiro, exista discurso externo do procedente, isto é, a fundamentação especifica da constituição da norma. (grifo meu) (Cramer, 2016, p.136).

Para tornar viável a dinâmica do precedente (tanto persuasivo, quanto vinculante), por força do inciso $\mathrm{V}$ do $\S 1^{\circ}$ do art. 489 do CPC, o juiz deve demonstrar e justificar a aplicação do precedente ao caso concreto quando houver identidade de tese jurídica e semelhança de fatos entre os casos. O caráter vinculante do precedente está na obrigatoriedade de sua aplicação caso haja identidade de teses e semelhanças de fatos, não importando se o aplicador concorda ou não com o precedente. A motivação específica está prevista, também, no $\S 1^{\circ}$ do art. 927 do CPC. Da mesma maneira, note-se que de acordo com o inciso VI do $\S 1^{\circ}$ do art. 489 do CPC, deverá o juiz motivar sua decisão, caso vá rejeitar a aplicação do precedente, se concluir que não há identidade de teses ou se verifica que há superação do precedente ${ }^{22}$ (Cramer, 2016, p. 139 e 140).

Obviamente, conseguir distinguir e agrupar semelhanças de fato e teses jurídicas é que se torna a tarefa ainda mais complicada. Muito bem explica o professor Ronaldo Cramer:

\footnotetext{
${ }^{22}$ Para distinguir, superar ou impugnar um precedente há métodos específicos, os quais não serão objeto de estudo do presente trabalho, mas podem ser encontrados nas obras de Fredie Didier, Ronal Cramer, Patrícia Perrone, Marinoni e outros.
} 
Identidade absoluta é aquela em que os casos apresentam identidade de fatos (não todos, mas somente aqueles que são relevantes para a controvérsia) e de questão jurídica, como se dá nas ações repetitivas, em que, a despeito das partes diferentes, existe a mesma tese jurídica. Exemplo: consumidores que discutem ser ilegal a cobrança de assinatura básica por partes das empresas de telefonia.

$\mathrm{E}$ casos de identidade essencial são aqueles que têm fatos completamente diferentes, mas possuem um núcleo fático e valoração jurídica idêntica. Exemplo: ação que reclama indenização por dano moral de dez mil reais pela perda de uma perna e ação que pede indenização por dano moral de cinquenta mil reais por um dedo decepado. Repare-se, nesse exemplo, que, muito embora os fatos sejam distintos (perna $\neq$ dedo e dez mil reais $\neq$ cinquenta mil reais), se pode extrair, minimamente, que as duas ações postulam dano moral por perda de um membro do corpo.

Veja-se que a diferença entre identidade absoluta e identidade essencial é muito sutil e subjetiva, podendo, em alguns casos, acontecer mais em função do modo como se argumenta a existência dessa identidade do que por sua existência em si. Além disso, se as duas identidades servem para o encaixe do precedente, talvez seja melhor elaborar uma única noção para determinar o que sejam casos idênticos.

Neste momento Cramer propõe a tese que nos parece a mais adequada:

Entendo que casos idênticos são aqueles que têm identidade de tese jurídica. A identidade de tese, por sua vez, configura-se a partir da cumulação de dois requisitos: (a) semelhança dos fatos referentes ao pedido ou à questão a ser julgada; $e(b)$ identidade dos fundamentos jurídicos desses fatos.

Por esse entendimento, a tese jurídica pode decorrer tanto do pedido formulado na ação quanto de uma questão incidental, que, não raras vezes, versa sobre matéria processual (como, por exemplo, a tese de cabimento de agravo de instrumento contra uma determinada decisão interlocutória).

Dá-se a semelhança de fatos, que não se confunde com identidade de fatos, quando os fatos essenciais para a compreensão do pedido ou da questão são parecidos ou têm aspectos comuns. Já identidade de fundamentos jurídicos se configura quando a valoração jurídica dos fatos semelhantes é a mesma.

Insista-se: casos com a mesma tese constituem aqueles em que as partes, causa de pedir e pedido podem ser formalmente distintos, mas o pedido ou a questão a ser apreciada se baseia em fatos semelhantes e em fundamentos jurídicos idênticos. (Cramer, 2016, p. 143-144).

Para esclarecer de maneira mais completa e didática as afirmações acima, Cramer dá o seguinte exemplo:

O STJ profere precedente, dizendo que o mero inadimplemento de obrigação contratual não acarreta dano moral. $O$ precedente foi fixado num julgado em que os fatos da causa diziam respeito ao descumprimento de obrigação prevista num contrato de franquia, e o autor descreve que esse comportamento lhe gerou grave frustração a ensejar reparação por dano moral. O caso concreto, em que a aplicação do precedente está sendo cogitada, trata de descumprimento de obrigação de um contrato de compra e venda, e o autor também narra que 
essa conduta antijurídica lhe gerou graves dissabores que justificam a reparação por dano moral. (grifo meu) (Cramer, 2016, p. 144).

Nota-se que os fatos são semelhantes, porém não idênticos, apesar de a tese jurídica ser a mesma, tornando possível a aplicação do precedente.

\subsection{Consequências da adoção do sistema de precedentes no}

\section{Direito brasileiro}

Ao adotar o sistema de precedentes e dar a alguns deles eficácia vinculante, será preciso repensar certos princípios e regras, a fim de adequálos à nova realidade. Como o tema ainda é muito recente, não se sabe se essas normas terão efetividade e, consequentemente, se acarretará profundas mudanças. Fato é que, para dar certo, será preciso mudar certos hábitos.

Uma mudança essencial é a forma de julgamento nos órgãos colegiados dos tribunais em que os votos são colhidos pelo presidente do órgão para posteriormente se saber se o magistrado concorda ou não com o resultado do voto do relator. Na aplicação do sistema de precedentes, conforme dito inúmeras vezes, é preciso identificar a ratio que se encontra na fundamentação do julgado. Sem essa fundamentação no julgamento colegiado e sem os motivos do voto do relator é impossível identificar e aplicar o precedente.

O princípio da legalidade, disposto no art. $8^{\circ}$ do CPC, por sua vez, deverá ser interpretado para além da mera aplicação da lei. A premissa de que o juiz deve decidir em conformidade com o Direito, e não mais apenas na lei (que é apenas uma das fontes do ordenamento jurídico), decorre do art. 926 do CPC que corrobora a necessidade de ressignificação desse princípio ao tornar obrigatória o dever de observância dos precedentes judiciais (Diddier Jr. et al, 2016, p. 481). 
Sob o mesmo argumento, deve-se olhar de modo diferente para o princípio da igualdade do caput do art. $5^{\circ}$ da Constituição Federal. Todos não são iguais perante a "lei", mas sim perante a "norma jurídica". Além disso, Marinoni aponta para a necessidade de se enxergar a igualdade perante as decisões judiciais (Diddier Jr. et al, 2016, p. 481). O sistema de precedente vem justamente trazer essa igualdade, pois o não tratamento isonômico de situações concretas só ocorre quando o entendimento é unificado, uniforme, coerente e estável, conforme impõe o art. 926 do CPC. Da mesma forma que o novo sistema pode trazer vantagens, o uso desarrazoado do mesmo também pode causar injustiças. Nesse sentido, destacam Fredie Didier Jr. et al:

Por isso, os arts. $489, \S 1^{\circ}, \mathrm{V}$ e VI e $927, \S 1^{\circ}$, exigem que todo julgador, ao aplicar ou afastar um precedente, o faça considerando se ele se ajusta ou não às peculiaridades fáticas do caso em julgamento; é dizer, verificando se há uma similitude fática entre o caso paradigma e o caso em julgamento, mediante a técnica da distinção. (Didier Jr., 2016, p. 482).

O princípio da segurança jurídica decorrente do art. 5º XXXVI da $\mathrm{CF}$, tem como objetivo assegurar que situações consolidadas no passado sejam respeitadas no presente e futuro (Didier Jr., 2016, p. 482). No entanto, a segurança jurídica não pode se pautar apenas em situações passadas, é preciso, também, garantir que as situações presentes sejam estáveis, tendo em vista que as pessoas podem moldar sua conduta presente nas soluções atuais do Poder judiciário, enquanto o legislador garante a previsibilidade dessas decisões. (Didier Jr., 2016, p. 483). E é sob esse aspecto que o princípio da segurança jurídica impõe o dever de se respeitar e seguir os precedentes judicias e seus efeitos, com o intuito de evitar a propagação de teses jurídicas díspares para situações semelhantes ${ }^{23}$.

Podemos ainda citar o princípio do contraditório como outro fator a ser redimensionado, a partir do momento em que percebemos que, em processos específicos, constitui-se uma norma geral aplicável a situações

${ }^{23}$ Fredie Didier Jr. et al destacam entre o princípio da segurança jurídica e o princípio do contraditório, o princípio da regra da motivação das decisões judiciais, a qual já foi citada, especificamente, no subitem anterior, ligado às novas previsões do art. 489 do CPC. 
futuras. Isso porque, "o princípio do contraditório, visto como direito de participação na construção da norma jurídica" (Didier Jr. et al, 2016, p. 485), não pode ser mais visto como um direito de participar da construção de uma norma jurídica individualizada, em uma única demanda, por exemplo, mas sim de uma norma jurídica geral. 


\section{CONCLUSÃO}

O direito é um sistema vivo, capaz de se transformar conforme o contexto histórico-social que está inserido. Ou o contrário, é um sistema vivo capaz de transformar a realidade da sociedade na qual está inserido. Estamos em constante evolução e o direito, como meio de controle social, precisa acompanhar essa evolução.

As mudanças no sistema do Civil Law podem vir por sua principal fonte: novas leis. Mas seria ingenuidade achar que só elas deveriam/poderiam acompanhar com rapidez e eficácia as mudanças sociais. Além disso, tendo em vista que vivemos num Estado Democrático de Direito, no qual os três poderes devem dialogar entre $\mathrm{si}^{24} \mathrm{em}$ busca do melhor para a sociedade, seria desarrazoado e autoritário que só o legislativo fizesse parte desse processo de evolução.

Fato é que, com o tempo e com a prática, foi-se percebendo que a aplicação literal das leis ao caso concreto pelo intérprete não é suficiente. Como vimos ao longo do trabalho, existem várias problemáticas que surgem na hora da aplicação da lei, nas quais cabe ao juiz resolver.

A primeira delas é o da indeterminação da linguagem. A partir do momento que se admite que a linguagem é algo construído socialmente, de acordo com os contextos e seus interlocutores, passa a ser inadmissível que uma regra/princípio seja aplicado só para o único contexto em que eles foram criados.

A segunda problemática é a textura aberta dos termos em geral e dos dispositivos jurídicos. Da mesma forma que a linguagem é construída

\footnotetext{
${ }^{24} \mathrm{O}$ termo "interlocução institucional" está presente na obra de Conrado Hübner Mendes, na qual ele defende que deve haver uma "briga" entre os três poderes, com o intuito de enriquecer a busca da sociedade pela proteção e desenvolvimento dos direitos individuais, que vão além do bem-estar da sociedade. Isso porque, a partir do momento que temos todos os poderes de um Estado Democrático de Direito, "brigando" para alcançar esse objetivo, quem sai ganhando é o povo. (Mendes, 2011).
} 
através do uso, e não trata-se de um objeto pré-determinado, os textos a serem interpretados e as normas a serem aplicadas também não o são.

Vimos que muitas vezes é preciso driblar vaguezas e ambiguidades dos dispositivos normativos, surgindo, assim, a necessidade de interpretálos para que as normas deles extraídas possam ter uma aplicação eficaz à realidade fática.

Nessa linha, chega-se à incontornável questão de se diferenciar o texto jurídico da norma efetivamente aplicada. Isso porque, já que o dispositivo editado pelo legislador está expresso numa linguagem coloquial passível de ser interpretada de acordo com o contexto que está inserida e composta por termos que possivelmente possuem texturas abertas, ela acaba se transformando em apenas um núcleo duro interpretativo, o qual vai direcionar as normas que podem dela emanar. E é na distinção entre texto e norma que o fato jurídico aparece como protagonista para a aplicação da decisão jurídica.

A triangulação texto-fato-norma é a base da formação do precedente e, consequentemente, da aplicação desse instituto. Chego a essa conclusão pois, conforme exposto ao longo do trabalho, um precedente, ao ser proferido pelo juiz, ou melhor, no seu momento de formação, não é ainda efetivamente um precedente, mas sim apenas um primeiro julgado. Desse primeiro julgado, mais precisamente da fundamentação desse primeiro julgado, que se extrairá a ratio: a norma jurídica geral a ser adotada em casos posteriores, caso venham a ocorrer.

Não obstante o primeiro julgado criar uma norma geral para os casos posteriores, tais casos deverão possuir semelhanças de fato e identidade de tese jurídica para tornar factível a aplicação do precedente que deverá novamente ser interpretado. Assim, além de o fato jurídico ser imprescindível para o primeiro processo de interpretação do texto legal (na medida em que a partir dele que se cria a norma específica aplicável ao 
caso), ele também será imprescindível para a extração da norma geral (ratio). Consequentemente, o primeiro caso que gerou o primeiro julgado também é imprescindível para o segundo processo de interpretação necessário para a identificação da semelhança dos fatos e da identidade de teses e para, por fim, poder aplicar a norma geral aos casos posteriores. E, assim, chega-se a uma última possível consequência: a reiteração do uso do precedente gerará a jurisprudência.

O propósito de fazer e estudar essa ligação entre a indeterminação da linguagem, interpretação jurídica e a triangulação texto-fato-norma é comprovar que é preciso admitir a complexidade da linguagem, admitir suas diferentes texturas para ao final promover uma melhora no tratamento dos casos que chegam ao judiciário. Diante das limitações de um trabalho monográfico, não tenho a pretensão de apresentar soluções para se ultrapassar a dificuldade processual-linguístico-filosófica na formação da ratio do precedente, mas apenas chamar atenção para tais questões e apontar para futuros estudos.

Não é crível que uma questão tão complexa quanto essa continue sendo tratada de forma simples, deixando que o Poder Judiciário siga sem coerência, sem uniformidade, sem segurança jurídica, sem estabilidade e sem integridade. Não é, ainda, eficiente o Judiciário julgar cada ação que repete a mesma tese jurídica, quando já há entendimento firmado sobre um assunto. Perde-se assim, tempo e qualidade. Resolvida a tese jurídica, essa deve ser aplicada pelos tribunais para que todos os processos que tenham por objeto essa tese, tenham a mesma solução.

Preocupados com o caos estabelecido no cenário atual, o legislador promove mudanças importantes no Novo Código de Processo Civil: institui precedentes vinculantes, estabelece deveres que possibilitam a construção e manutenção de um sistema de precedentes e consequentemente introduzem a adoção do stare decisis no ordenamento jurídico brasileiro, bem como 
formalizam a importância da fundamentação das decisões (para que se possa extrair tanto a norma individual, quanto a ratio) e o encaixe do precedente ao caso concreto.

Essa nova perspectiva corrobora com a ideia desenvolvida nessa monografia e com a problemática apontada. Assim, se espera que a partir da introdução do instituto do precedente, os operadores do direito fiquem mais atentos às complexidades da linguagem e, em consequência, reflitam sobre a necessidade e o esforço de superá-la na extração de normas gerais e na aplicação dos precedentes, com o intuito de diminuir a insegurança jurídica que hoje assombra todos os cidadãos brasileiros. 


\section{BIBLIOGRAFIA}

ANDRADE, José Maria Arruda, Hermenêutica jurídica e a questão da textura aberta. Revista da Faculdade de Direito da Universidade de São Paulo, v. 103, 2008.

ÁVILA, Humberto. Teoria dos Princípios - da definição à aplicação dos princípios jurídicos, $11^{\mathrm{a}}$ edição revista, São Paulo: Malheiros Editores, 2010.

BARROSO, Luis Roberto, Doze Anos de Constituição Brasileira de 1988: Uma breve e Acidentada História de Sucesso. In: BARROSO, Luis Roberto. Temas de Direito Constitucional. Rio de Janeiro: Renovar, 2005.

CAPPELlETTI, Mauro. O Processo Civil Italiano no Quadro da Contraposição "Civil Law" - "Commom Law: Apontamentos HistóricoComparativos". Revista da AJURIS. Porto Alegre, n. 100, dez. 2005.

CRAMER, Ronaldo. Precedentes judiciais: teoria e dinâmica, 1.ed, Rio de Janeiro: Forense, 2016.

DIMOULIS, Dimitri. Manual de introdução ao estudo do direito. São Paulo: Editora Revista dos Tribunais, 2007, 2a edição.

MARINONI, Luiz Guilherme. Precedentes Obrigatórios. 4. ed. rev., atual e amp. - São Paulo: Revista dos Tribunais, 2016.

MAXIMILIANO, Carlos. Hermenêutica e Aplicação do Direito. $11^{\circ}$ edição, Forense, Rio de Janeiro, 1991.

MELlO, Patrícia Perrone de Campos. Precedentes $-O$ desenvolvimento judicial do direito no constitucionalismo contemporâneo, Ed. Renovar, 2008.

MENDES, Conrado Hübner. Direitos Fundamentais, Separação de Poderes e Deliberação. Ed. Saraiva, 2011. 
MENDES, Conrado Hubner, "Lendo uma decisão: obiter dictum e ratio decidendi. Racionalidade e retórica na decisão" - disponível em: <http://www.sbdp.org.br/arquivos/material/19_Estudo\%20dirigido\%20\%20 Ratio\%20decidendi\%20e\%20obter\%20dictum\%20\%20Conrado\%20Hubne r\%20Mendes.pdf > Último acesso em 08.10.2016.

MÜLLER, Friedrich. O Novo Paradigma do Direito. $3^{\circ}$ edição, Editora RT, São Paulo, 2013.

NEVES, Marcelo. Entre Hidra e Hércules: princípios e regras constitucionais como diferença paradoxal do sistema jurídico. São Paulo: Editora WMF Martins Fontes, 2013 - Biblioteca jurídica WMF.

NIGRO, Rachel, "A virada linguístico-pragmática e o pós-positivismo", Rio de Janeiro, Revista Direito, Estado e Sociedade, no 34, 2009 disponível em $\quad$ http://direitoestadosociedade.jur.pucrio.br/media/nigro direito34.pdf $>$ último acesso em 11.11 .2016 Desconstrução Linguagem Política, tese de doutorado, 2007.

RODRIGUEZ, José Rodrigo; COSTA, Carlos Eduardo Batalha da Silva e; BARBOSA, Samuel Rodriguez. Nas fronteiras do formalismo: a função social da dogmática jurídica hoje. São Paulo: Saraiva, 2010.

SANTIAGO, Carlos Nino, Introdução à Análise do Direito, $1^{\mathrm{a}}$ ed., São Paulo: WMF Martins Fontes, 2010.

STRUCHINER, Noel. Verbete Filosofia da Linguagem. In: BARRETO, Vicente. Dicionário de Filosofia do Direito. Renovar, Rio de Janeiro, 2006.

STRUCHINER, Noel. Direito e Linguagem. Uma análise da textura aberta da linguagem e sua aplicação ao Direito. Biblioteca de teses, Ed. Renovar, Rio de Janeiro, 2002, - disponível em:

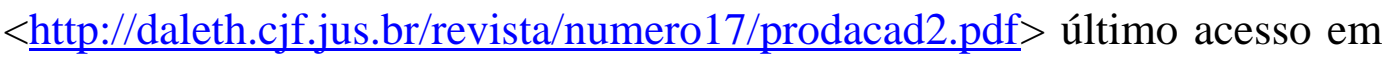
11.11.2016 
STRUCHINER, Noel. Para falar de regras - O positivismo Conceitual como Cenário para uma Investigação Filosófica acerca dos Casos Difíceis, Teses de Doutorado, Rio de Janeiro, 2005. 